\title{
Milk production and efficiency of utilization of nitrogen, metabolizable protein, and amino acids are affected by protein and energy supplies in dairy cows fed alfalfa-based diets
}

\author{
J.-P. Laroche, ${ }^{1,2} \odot$ R. Gervais, ${ }^{1} \odot$ H. Lapierre, ${ }^{3} \odot$ D. R. Ouellet, ${ }^{3} \odot$ G. F. Tremblay, ${ }^{4} \oplus$ C. Halde,${ }^{5} \odot$ \\ M.-S. Boucher, ${ }^{5}$ and É. Charbonneau ${ }^{1 *}$ (D) \\ ${ }^{1}$ Département des Sciences Animales, Université Laval, Québec, QC, Canada, G1V OA6 \\ ${ }^{2}$ Lactanet, Sainte-Anne-de-Bellevue, QC, Canada, H9X 3R4 \\ ${ }^{3}$ Sherbrooke Research and Development Centre, Agriculture and Agri-Food Canada, Sherbrooke, QC, Canada, J1M 0C8 \\ ${ }^{4}$ Quebec Research and Development Centre, Agriculture and Agri-Food Canada, Québec, QC, Canada, G1V 2J3 \\ ${ }^{5}$ Département de Phytologie, Université Laval, Québec, QC, Canada, G1V 0A6
}

\section{ABSTRACT}

Alfalfa has a lower fiber digestibility and a greater concentration of degradable protein than grasses. Dairy cows could benefit from an increased digestibility of alfalfa fibers, or from a better match between nitrogen and energy supplies in the rumen. Alfalfa cultivars with improved fiber digestibility represent an opportunity to increase milk production, but no independent studies have tested these cultivars under the agroclimatic conditions of Canada. Moreover, decreasing metabolizable protein (MP) supply could increase $\mathrm{N}$ use efficiency while decreasing environmental impact, but it is often associated with a decrease in milk protein yield, possibly caused by a reduced supply of essential AA. This study evaluated the performance of dairy cows fed diets based on a regular or a reduced-lignin alfalfa cultivar and measured the effect of energy levels at low MP supply when digestible His (dHis), Lys (dLys), and Met (dMet) requirements were met. Eight Holstein cows were used in a double $4 \times 4$ Latin square design, each square representing an alfalfa cultivar. Within each square, 4 diets were tested: the control diet was formulated for an adequate supply of MP and energy ( $\mathrm{AMP}_{-}$ $\mathrm{AE}$ ), whereas the 3 other diets were formulated to be deficient in MP (DMP; formulated to meet $90 \%$ of the MP requirement) with deficient (94\% of requirement: DMP_DE), adequate (99\% of requirement: DMP_ AE), or excess energy supply (104\% of requirement; DMP_EE). Alfalfa cultivars had no significant effect on all measured parameters. As compared with cows receiving AMP_AE, the dry matter intake of cows fed

Received June 25, 2021.

Accepted August 26, 2021.

*Corresponding author: edith.charbonneau@fsaa.ulaval.ca
DMP_AE and DMP_EE was not significantly different but decreased for cows fed DMP_DE. The AMP_AE diet provided $103 \%$ of $\mathrm{MP}$ and $108 \%$ of $\mathrm{NE}_{\mathrm{L}}$ requirements whereas DMP_DE, DMP_AE, and DMP_EE diets provided 84,87 , and $87 \%$ of MP and 94,101 , and $107 \%$ of $\mathrm{NE}_{\mathrm{L}}$ requirements, respectively. In contrast to design, feeding DMP_EE resulted in a similar energy supply compared with AMP_AE, although MP supply has been effectively reduced. This resulted in a maintained milk and milk component yields and improved the efficiency of utilization of N, MP, and essential AA. The DMP diets decreased total $\mathrm{N}$ excretion, whereas DMP_AE and DMP_EE diets also decreased milk urea- $\mathrm{N}$ concentration. Reducing MP supply without negative effects on dairy cow performance is possible when energy, dHis, dLys, and dMet requirements are met. This could reduce $\mathrm{N}$ excretion and decrease the environmental impact of milk production.

Key words: amino acid, histidine, rumen-protected lysine, rumen-protected methionine, fatty acid

\section{INTRODUCTION}

Alfalfa (Medicago sativa L.) is the most widely grown forage legume in Canada (Statistics Canada, 2021). Legumes have a lower fiber concentration than grasses, but their fibers are generally less digestible (Hoffman et al., 1998). Based on intake potential and energy availability, increasing digestibility of legume cell walls would be beneficial for ruminants (Jung and Allen, 1995). In addition, alfalfa has a high CP concentration, but a large portion of this CP is either NPN or true protein highly degradable in the rumen (NRC, 2001). Utilization of these highly degradable $\mathrm{CP}$ by rumen microorganisms could be enhanced by a greater availability of energy substrates in the rumen. Therefore, increasing the digestibility of legume cell walls would 
also be beneficial for ruminants by increasing rumen microbial protein synthesis (Jung and Allen, 1995).

Improving fiber digestibility would be an opportunity to increase profitability and decrease environmental impacts for the dairy sector (Hatfield et al., 1999). According to a meta-analysis (Oba and Allen, 1999), an increase of 1 percentage unit of in vitro or in situ NDF digestibility (NDFd) is associated with a 0.25 $\mathrm{kg} / \mathrm{d}$ increase in $4 \%$ FCM. Several alfalfa cultivars with enhanced digestibility have recently been commercialized in North America. Given the lack of independent studies testing these cultivars under the agroclimatic conditions of Canada, our first objective was to verify the potential benefits of using an alfalfa cultivar with improved digestibility in dairy rations.

Increasing prices of feed ingredients and the need to reduce environmental impact of dairy production have stimulated interest in reducing $\mathrm{CP}$ concentration in dairy rations (e.g., Lee et al., 2012b). Dairy cows are regularly fed diets providing excess protein, whereas milk production and composition could be maintained, or even improved, with reduced CP content of the diets (Broderick, 2018). Reducing dietary CP concentration could enhance profitability by improving $\mathrm{N}$ efficiency from diet to milk while reducing $\mathrm{N}$ excretion in the environment (Holt et al., 2013). Although current protein requirements of dairy cows are expressed in MP rather than CP (e.g., NRC, 2001), cows fed diets providing the required MP supply might be overfed in some EAA and underfed in others, resulting in a poor $\mathrm{N}$ utilization efficiency (Arriola Apelo et al., 2014). A decrease in MP supply is often associated with a reduced milk protein yield (MPY), probably because requirements for one or many EAA are not met (Arriola Apelo et al., 2014). Therefore, it is of utmost importance to consider EAA supply when formulating low-MP dairy rations.

Methionine and Lys are usually considered as first limiting AA for milk protein production in cows fed typical North American dairy diets (NRC, 2001). However, because microbial protein has a lower His content than milk and feed ingredients (NRC, 2001; Sok et al., 2017), it may become a limiting AA for milk production and MPY in diets supplying a high proportion of MP from microbial protein, as is the case when low-MP diets are fed to dairy cows (Huhtanen et al., 2002; Lee et al., 2012c; Giallongo et al., 2016).

Effects of energy and MP supplies on MPY have been reported to be additive and independent (Broderick, 2003; Raggio et al., 2006; Omphalius et al., 2019a), except in one study (Brun-Lafleur et al., 2010). Increased energy intake or postruminal glucose infusion led to an increased efficiency use of MP, whereas an increased MP supply decreased it (Omphalius et al., 2019a,
2020). Maintaining an adequate supply of EAA with a reduced supply of MP combined with an increased energy supply might further increase MP efficiency use and MPY.

Therefore, the objectives of the current study were (1) to compare the performance of dairy cows fed a diet based on a regular alfalfa cultivar to those fed a diet based on a cultivar selected for its reduced lignin concentration; and (2) to determine the effect of decreasing MP supply but maintaining adequate His, Lys, and Met supplies at different energy levels on cow performance and efficiency of $\mathrm{N}$ utilization. We hypothesized that cows fed an alfalfa cultivar selected for its reduced lignin concentration would have a greater DMI and produce more milk. We also hypothesized that, for a same energy supply, cows fed a MP-deficient diet with adequate His, Lys, and Met supplies would have a comparable MPY than cows fed a MP-adequate diet, and that increasing dietary energy content at low MP but adequate His, Lys, and Met supplies would lead to a further increment of MPY and efficiency of $\mathrm{N}$ utilization.

\section{MATERIALS AND METHODS}

\section{Haylage Production}

Two alfalfa cultivars were seeded on an area of 16 ha at the Université Laval's agronomic research station in Saint-Augustin-de-Desmaures $\left(46^{\circ} 43^{\prime} 26^{\prime \prime} \mathrm{N}\right.$, $\left.71^{\circ} 30^{\prime} 1^{\prime \prime} \mathrm{W}\right)$. Four fields were sown with both cultivars; to avoid contamination between them, some parts of the fields were not harvested. A regular alfalfa cultivar ('Calypso', Sollio Cooperative Group; as control) and an alfalfa cultivar selected for its reduced lignin concentration ('Boost' HG, Quality Seeds) were used for the experiment (Table 1$)$.

In the first postseeding year, the first cut of alfalfa was harvested on June 19, 2018, at the early-bloom stage of development with a disc mower (Krone Easy Cut 9140 HP, Krone NA Inc.). Forages were wilted in the field until they reached about $45 \%$ of DM to promote preservation without the addition of inoculants (Coblentz et al., 2016). Forages were then harvested as large rectangular bales with a roto-cut press (Kuhn LSB 890 D, Kuhn) and plastic coated with a wrapper (Anderson SB-780, Groupe Anderson Inc.).

\section{Cows, Diets, and Experimental Design}

The experiment was carried out at the Centre de Recherche en Sciences Animales de Deschambault (QC, Canada) from March to May 2019. All procedures in- 
volving dairy cows were approved by the animal care committee of Université Laval in accordance with the guidelines of the Canadian Council on Animal Care (CCAC, 2009). We used 8 multiparous Holstein dairy cows, averaging at the initiation of the trial (mean \pm SD) $117 \pm 42$ DIM, $764 \pm 79 \mathrm{~kg}$ of BW, and $40.9 \pm$ $4.8 \mathrm{~kg}$ of milk/d, housed in a tiestall barn. Parity of the cows was on average 3.5 (25\% second lactation, $25 \%$ third lactation, $50 \%$ greater than third lactation). Animals were distributed in a double $4 \times 4$ Latin square design balanced for residual effects, with 21-d periods.

Cows were assigned to each Latin square ensuring that the average milk yield and DIM was equivalent between squares. Cows of the first square $(41.9 \pm 5.3 \mathrm{~kg}$ of milk/d; $109 \pm 41$ DIM; mean \pm SD) were fed haylage made with the regular alfalfa cultivar, whereas those of the second square $(39.9 \pm 4.9 \mathrm{~kg}$ of milk/d; $124 \pm 47$ DIM) were fed haylage made with the reduced-lignin alfalfa cultivar. In each square, cows were randomly assigned to treatments according to a $4 \times 4$ Latin square design. Energy and protein requirements were based on milk production and intake measured $3 \mathrm{~d}$ before the beginning of the experiment. Considering the data collected during this pre-experimental period, diets were formulated to meet the nutritional requirements of a 764- $\mathrm{kg}$ lactating cow, eating $27.2 \mathrm{~kg} \mathrm{DM} / \mathrm{d}$, and producing $40.9 \mathrm{~kg}$ milk/d with a concentration of milk fat and true protein of $3.90 \%$ and $3.17 \%$, respectively. Treatments were 4 diets: the control diet supplied

Table 1. Chemical composition of alfalfa haylages

\begin{tabular}{|c|c|c|}
\hline \multirow[b]{2}{*}{ Chemical component $^{1}$} & \multicolumn{2}{|c|}{ Alfalfa } \\
\hline & $\begin{array}{l}\text { Cultivar } \\
\text { Calypso }^{2}\end{array}$ & $\begin{array}{l}\text { Cultivar } \\
\text { Boost } \mathrm{HG}^{3}\end{array}$ \\
\hline $\mathrm{DM}$ (\% as fed) & 42.9 & 43.6 \\
\hline $\mathrm{OM}$ & 90.2 & 89.5 \\
\hline $\mathrm{CP}$ & 18.1 & 16.8 \\
\hline $\mathrm{aNDF}^{4}$ & 43.7 & 44.9 \\
\hline $\mathrm{ADF}$ & 37.4 & 37.7 \\
\hline ADL & 8.5 & 8.6 \\
\hline IVTD $^{5}$ & 77.9 & 76.7 \\
\hline 48-h $\mathrm{NDFd}^{6}(\%$ aNDF $)$ & 49.5 & 48.2 \\
\hline $\mathrm{uNDF}_{240}{ }^{7}$ & 21.2 & 22.5 \\
\hline Ether extract & 2.7 & 2.6 \\
\hline $\mathrm{Ca}$ & 1.30 & 1.35 \\
\hline $\mathrm{P}$ & 0.27 & 0.29 \\
\hline
\end{tabular}

${ }^{1}$ Percent of DM, unless specified.

${ }^{2}$ Haylage made with the control cultivar (Sollio Cooperative Group).

${ }^{3}$ Haylage made with the reduced-lignin cultivar (Quality Seeds).

${ }^{4}$ Neutral detergent fiber assayed with a heat-stable amylase and sodium sulfite.

${ }^{5}$ In vitro true digestibility.

${ }^{6} \mathrm{NDF}$ digestibility.

${ }^{7}$ Undigested NDF estimated via 240 -h in vitro fermentation. adequate levels of MP and energy (AMP_AE; i.e., $100 \%$ of requirements; NRC, 2001), whereas the 3 other diets were MP deficient (DMP), formulated to meet $90 \%$ of MP requirement (NRC, 2001) with deficient (94\% of requirement: DMP_DE), adequate (99\% of requirement: DMP_AE), or excess supply of energy (104\% of requirement; DMP_EE). Metabolizable protein requirement was estimated at $2,895 \mathrm{~g} / \mathrm{d}$ and the 3 DMP diets were estimated to be $276 \mathrm{~g} \mathrm{MP} / \mathrm{d}$ deficient. Energy requirement was estimated at $41.5 \mathrm{Mcal} \mathrm{NE} / \mathrm{d}$ and supply of $\mathrm{NE}_{\mathrm{L}}$ was estimated to be 41.5, 39.2, 41.1, and $43.0 \mathrm{Mcal} / \mathrm{d}$ for AMP_AE, DMP_DE, DMP_AE, and DMP_EE diets, respectively. As the analyses did not indicate any difference in chemical composition and digestibility between alfalfa haylages (Table 1), the average nutrient composition of both alfalfa haylages was used to formulate diets. Requirements of Met and Lys were estimated at $2.38 \%$ and $6.95 \%$ of MP supply from the AMP_AE diet, respectively (Whitehouse et al., 2010a,b); these amounts in grams per day were maintained in the DMP diets. As a consequence, His, Lys, and Met supplies expressed as percentages of MP were higher for DMP treatments. Because metabolisms of His and Met are similar in splanchnic and mammary gland tissue (Lapierre et al., 2012) and because these AA have a similar concentration in milk protein (Lapierre et al., 2020), His requirement was assumed to be similar to that of Met. Rumen-protected (RP) AA were used to ensure a sufficient supply of Lys and Met. Sources of supplemental RP-Lys and RP-Met were AjiPro-L 3rd Generation (Ajinomoto Heartland Inc.) and Smartamine M (Adisseo NA), respectively. The AjiProL supplement contained $41 \%$ of Lys with a bioavailability of $30 \%$ (information from feed manufacturer). The Smartamine M supplement contained $75 \%$ of Met with a bioavailability of $71 \%$ (information from feed manufacturer). Blood meal (Agribrands Purina Canada Inc.) was used as a His source. Therefore, requirements of digestible His (dHis) were estimated at $69 \mathrm{~g} / \mathrm{d}$ with all diets providing $67 \mathrm{~g} / \mathrm{d}$; requirements of digestible Lys (dLys) were estimated at $201 \mathrm{~g} / \mathrm{d}$ with all diets providing $205 \mathrm{~g} / \mathrm{d}$; and requirements of digestible Met (dMet) were estimated at $69 \mathrm{~g} / \mathrm{d}$ with all diets providing $67 \mathrm{~g} / \mathrm{d}$. Experimental diets were formulated to meet the requirements for all other nutrients according to NRC (2001). The supply of RDP was ensured to be adequate with urea being added to the DMP diets.

Diets were mixed using a Rovibec Supermix RTM 530 (Rovibec Agrisolutions) and fed as a TMR once daily at $0930 \mathrm{~h}$. Diets were pushed in front of the cows at least 6 times daily. The RP AA supplements and urea were top-dressed and mixed with $100 \mathrm{~g}$ of ground corn $2 \mathrm{~h}$ after the TMR feeding. Visual observation 
confirmed that top-dress was completely consumed. Cows had free access to drinking water at all time. During the experiment, DM concentration of forages were determined twice a week to adjust composition of diets on an as-fed basis. The amount of feed offered was adjusted daily to ensure $10 \%$ refusals on an as-fed basis.

\section{Measurements and Sampling}

Refusals were weighed daily just before feeding. Samples of TMR, refusals, and ingredients were collected from d 18 to 21 of each period, composited by cow within period (TMR and refusals) or by period (ingredients), and stored at $-20^{\circ} \mathrm{C}$ for further analysis. The BCS were determined accordingly to Edmonson et al. (1989) at $1340 \mathrm{~h}$ on d 19 and 20, whereas BW of cows were recorded at $1340 \mathrm{~h}$ on d 15 to 17 .

Total excreted feces were collected and weighed daily $(1100 \mathrm{~h})$ from d 18 to 21 . Daily samples representing $0.5 \%$ of the total amount excreted, on a fresh basis, were frozen at $-20^{\circ} \mathrm{C}$ and further pooled by cow within period before analysis. For urine collection, catheters (24 mm, 75-mL balloon, Bardex Lubricath Foley Catheters, Bard Medical Division) were inserted into the bladder of each cow on d 17 and were connected to a plastic container using a polyvinyl chloride tubing at $1100 \mathrm{~h}$ the next day. Then, $200 \mathrm{~mL}$ of diluted sulfuric acid (50:50) was added to the container 3 times daily to prevent ammonia volatilization. Total urine was weighed and sampled daily $(1100 \mathrm{~h})$ from d 18 to 21 . Density was determined by weighing $500 \mathrm{~mL}$ of urine. Two subsamples of urine were collected, one pure and one diluted $(1: 4, \mathrm{wt} / \mathrm{wt})$ for purine derivatives (PD) and creatinine analysis. All samples were immediately frozen at $-20^{\circ} \mathrm{C}$ and further pooled by cow within period for subsequent analyses.

Cows were milked twice daily at 0715 and $1640 \mathrm{~h}$. Milk yield was measured using calibrated Tru-Test milk meters (Datamars). Milk samples were collected at each milking for the last 6 milkings from d 18 p.m. to d 21 a.m. Samples from the p.m. milking were stored at $4^{\circ} \mathrm{C}$ until they were mixed with samples from the next a.m. milking, proportionally to milk yield. Composited samples were stored at $4^{\circ} \mathrm{C}$ with 2-bromo-2-nitropropane-1,3-diol until further determination of milk fat, $\mathrm{CP}$, lactose, and MUN. Additional milk samples were collected and stored at $-20^{\circ} \mathrm{C}$ without preservative, and further pooled by cow within period for subsequent NPN and fatty acid analyses.

On d 20, blood samples were taken from the tail of all cows before a.m. milking $(0650 \mathrm{~h})$ and $4 \mathrm{~h}$ after feeding $(1330 \mathrm{~h})$. Samples were collected into heparinized and EDTA vacutainer tubes (Becton Dickinson), and immediately put on ice. Tubes were then centrifuged at $1,800 \times g$ for $15 \mathrm{~min}$ at $4^{\circ} \mathrm{C}$ to collect plasma, of which different aliquots were stored at -20 and $-80^{\circ} \mathrm{C}$ until chemical analyses.

\section{Chemical Analyses}

Feed, Feces, and Urine. Dry matter concentration of ingredients, TMR, and refusals was determined by freeze-drying. All these dried samples were then ground to $1 \mathrm{~mm}$ using a Wiley mill (model 3, Arthur H. Thomas Co.). After air acclimatization, concentrations of analytical DM and ash in dried and ground samples were determined using a thermogravimetric analyzer (Leco model TGA 701, Leco Corp.). The concentration of neutral detergent insoluble fiber assayed with a heat-stable $\alpha$-amylase and sodium sulfite inclusive of residual ash (aNDF) was determined following Mertens (2002). The ADF and ADL concentration was determined following AOAC (1990). All fiber extractions were done using the Ankom filter bag (F57; 25 $\mu \mathrm{m}$ porosity) technique (Ankom 2000 Fiber Analyzer). Samples were mineralized using a mixture of sulfuric and selenious acids as described by Isaac and Johnson (1976). This extract was used to determine total N (method 13-107-6-2-D; Lachat Instruments, 2019) using a Lachat QuikChem8000 flow injection analysis system (Zellweger Analytics Inc., Lachat Instruments Division). Concentrations of $\mathrm{P}$ and $\mathrm{Ca}$ were determined by inductively coupled plasma optical emission spectrometry (ICP-OES, Optima 4300DV, Perkin Elmer). Concentration of $\mathrm{CP}$ was calculated as total $\mathrm{N} \times 6.25$. Ether extract was determined according to the method of AOAC International (2005).

The in vitro true digestibility (IVTD) of DM was measured using the method of Goering and Van Soest (1970) based on a 48-h incubation with buffered rumen fluid followed by an aNDF determination of the postdigestion residues. The rumen fluid incubation was performed with Ankom F57 filter bags with an Ankom DaisyII incubator, using the batch incubation procedures outlined by Ankom Technology Corp. Rumen fluid was obtained from a lactating, ruminally fistulated dairy cow that was offered a diet of $42 \%$ corn silage, $38 \%$ mixed grass/legume silage, $2 \%$ soybean meal, and $18 \%$ concentrate mix. The diet was formulated to meet the nutritional requirements of a $670-\mathrm{kg}$ lactating cow producing $9,760 \mathrm{~kg}$ of milk per year. The IVTD (\% DM) was calculated as follows: IVTD $=[1-$ (postdigestion dry weight following aNDF wash/predigestion dry weight)] $\times 100$. The in vitro NDF digestibility ( $\mathrm{NDFd} \% \%$ aNDF) was calculated as follows: NDFd = 
$[1-$ (postdigestion dry weight following aNDF wash/ predigestion dry weight of aNDF) $] \times 100$.

The in vitro NDF digestibility at $240 \mathrm{~h}\left(\mathrm{NDFd}_{240}\right)$ was performed using procedures previously described for NDFd, but with a 240-h incubation time. The unavailable NDF $\left(\mathrm{uNDF}_{240}\right)$ fraction was calculated as $\mathrm{uNDF}_{240}=\left(100-\mathrm{NDFd}_{240}\right) \times \mathrm{aNDF} / 100$. To determine the fatty acid composition of TMR, direct transesterification was first performed, and FAME were then extracted following the method described by Jenkins (2010) with modifications. In the modified procedure, incubation in $3 \mathrm{~mL}$ of $\mathrm{HCl} 10 \%$ in methanol (vol/vol) was performed at $50^{\circ} \mathrm{C}$ for 30 min after a prior incubation in $3 \mathrm{~mL}$ of sodium methoxide $(0.5 \mathrm{M}$ in methanol) at $70^{\circ} \mathrm{C}$ for $60 \mathrm{~min}$.

Fecal samples were freeze-dried and ground to pass a 1-mm screen using a Wiley mill (model 3, Arthur M. Thomas Co.). Feces were then analyzed for DM, analytical DM, aNDF, ADF, $\mathrm{uNDF}_{240}, \mathrm{~N}$, and ash using procedures previously described for feed samples. Apparent digestibility of nutrients was calculated by subtracting daily excretion in feces from their daily intake.

Urinary analysis of $\mathrm{N}$ was performed using procedures previously described for feed samples. Urea-N was analyzed with an automatic analyzer (Technicon Autoanalyzer II, Technicon Instruments Corporation) as previously described by Huntington (1984). Creatinine and PD (allantoin and uric acid) were measured with a HPLC (1260 Infinity HPLC, Agilent Technologies) method adapted from George et al. (2006).

Milk. Milk samples with preservative were analyzed by infrared spectroscopy (Foss MilkoScan FT 6000) for fat, CP, lactose, and MUN at Lactanet (Dairy Production Center of Expertise, Québec and Atlantic, Sainte-Anne-de-Bellevue, QC, Canada). Samples without preservative were analyzed for NPN and fatty acid composition. The NPN was obtained by precipitation with trichloroacetic acid, with a final concentration of $12 \%$; it was then analyzed with the Kjeldahl method and subtracted (as total $\mathrm{N} \times 6.38$ ) from $\mathrm{CP}$ to obtain true protein. Milk fatty acid composition was determined according to the procedure described by Boivin et al. (2013).

Plasma. For plasma AA analysis, 1-g aliquots of plasma were added to $0.2 \mathrm{~g}$ of an internal AA standard labeled with stable isotopes as described in Doepel and Lapierre (2010). Labeled AA (95-99 atom\%) were supplied by CDN Isotopes for His, Leu, Lys, Met, and Phe and by Cambridge Isotope Laboratories for the other AA. Plasma AA concentrations were measured by isotope dilution using GC-MS (Calder et al., 1999) and $N$-(tert-butyldimethyl) AA derivative. Urea-N was analyzed using procedures previously described for urine. Using commercial kits, plasma was analyzed for concentrations of nonesterified fatty acids [NEFA; Wako HR series NEFA-HR (2) Kit, FUJIFILM Wako Diagnostics USA] and glucose (PGO assay, SigmaAldrich).

\section{Calculations and Statistical Analyses}

Whole-body efficiency was calculated following the principles proposed by INRA (INRA, 2018) for MP and used later (Lapierre et al., 2020; Omphalius et al., 2020) for individual EAA. Briefly, this efficiency is calculated as the sum of true protein or EAA in exported proteins; that is, milk true protein yield, scurf, and metabolic fecal protein divided by MP or EAA supply (minus endogenous urinary loss). Metabolic fecal and endogenous urinary losses were calculated based on Lapierre et al. (2020), whereas MP and EAA supply were estimated using NRC (2001), but the duodenal endogenous contribution was excluded.

The alfalfa cultivar was the main plot factor and within each forage source, the 4 dietary treatments (subplots) were distributed in replicate Latin square fashion. No data were excluded from the analysis. Data were analyzed using the MIXED procedure of SAS (version 9.4; SAS Institute Inc.) according to the following model:

$$
\begin{aligned}
\mathrm{Y}_{\mathrm{ijkl}}=\mu & +\mathrm{S}_{\mathrm{j}}+\mathrm{C}(\mathrm{S})_{\mathrm{lj}}+\mathrm{T}_{\mathrm{i}}+\mathrm{P}(\mathrm{S})_{\mathrm{kj}} \\
& +(\mathrm{T} \times \mathrm{S})_{\mathrm{ij}}+\varepsilon_{\mathrm{ijkl}},
\end{aligned}
$$

where $Y_{\mathrm{ijkl}}=$ individual observation, $\mu=$ overall mean, $\mathrm{S}_{\mathrm{j}}=$ fixed effect of square $(\mathrm{j}=1$ to 2$), \mathrm{C}(\mathrm{S})_{\mathrm{lj}}=$ random effect of cow $(1=1$ to 4$)$ within square, $\mathrm{T}_{\mathrm{i}}=$ fixed effect of treatment ( $\mathrm{i}=1$ to 4$), \mathrm{P}(\mathrm{S})_{\mathrm{kj}}=$ fixed effect of period $(\mathrm{k}=1$ to 4$)$ within square, $(\mathrm{T} \times \mathrm{S})_{\mathrm{ij}}=$ effect of the interaction between treatment and square, and $\varepsilon_{\mathrm{ijk}}$ $=$ residual error term. Differences between treatments were declared at $P \leq 0.05$, and tendencies from $0.05<$ $P \leq 0.10$. When the treatment effect was significant, means were separated using the PDIFF option with Tukey's adjustment.

Plasma urea-N, glucose, NEFA, and AA concentrations were initially analyzed as repeated measures according to the following model:

$$
\begin{aligned}
\mathrm{Y}_{\mathrm{ijklm}}=\mu & +\mathrm{S}_{\mathrm{j}}+\mathrm{C}(\mathrm{S})_{\mathrm{lj}}+\mathrm{T}_{\mathrm{i}}+\mathrm{P}(\mathrm{S})_{\mathrm{kj}}+(\mathrm{T} \times \mathrm{S})_{\mathrm{ij}} \\
& +\mathrm{H}_{\mathrm{m}}+(\mathrm{T} \times \mathrm{H})_{\mathrm{im}}+\varepsilon_{\mathrm{ijklm}},
\end{aligned}
$$

where $Y_{i j k l m}$ is the individual observation, $H_{m}$ is the effect of sampling time $(\mathrm{m}=0650$ and $1330 \mathrm{~h}),(\mathrm{T} \times \mathrm{H})$ 
im is the effect of the interaction between treatment and time of sampling, and $\varepsilon_{\mathrm{ijklm}}$ is the residual error term. Cow was considered as a random effect. The subject of the repeated measurements was cow (period $\times$ treatment), and the spatial covariance structure $\mathrm{SP}(\mathrm{POW})$ was used to estimate covariances. Because there was no sampling time $\times$ treatment interactions, mean values for plasma urea-N, glucose, NEFA, and AA concentrations were combined for statistical analysis according to the first model previously described. When the treatment effect was significant, means were separated using the PDIFF option with Tukey's adjustment.

\section{RESULTS AND DISCUSSION}

\section{Effect of Alfalfa Haylages Cultivars}

Chemical composition of alfalfa haylages was not affected by cultivars as illustrated by similar values for aNDF, ADF, ADL, IVTD, in vitro 48-h NDFd, and $\mathrm{uNDF}_{240}$ (Table 1). Consequently, no significant effect of the alfalfa cultivars or interaction with dietary treatments was observed on the different parameters measured in this experiment, including apparent digestibility of nutrients. Further research is therefore needed with alfalfa cultivars that show a tangible difference in their digestibility to assess the in vivo effect of a more digestible alfalfa cultivar grown in Canada on the performance of dairy cattle. Many factors not controlled in our study may have prevented the improved alfalfa cultivar to express its enhanced digestibility potential. Air temperature, water stress, and even location can alter digestibility of alfalfa (Vough and Marten, 1971; Julier and Huyghe, 1997; Lauzon et al., 2019). Using in situ evaluation, it has also been reported that alfalfa cultivars selected for improved digestibility were not always more digestible than regular cultivars (Grev et al., 2017). Given the absence of significant effects of alfalfa cultivar, it will not be further discussed, and results will be presented for the 4 diets only.

\section{Dietary Contrasts: Realized vs. Objective}

As planned, all DMP diets had lower CP concentrations than AMP_AE diet (Table 2). To achieve this, soybean meal was removed, and ground corn was partially replaced with corn starch in DMP diets. Also, concentrations of $\mathrm{NE}_{\mathrm{L}}$ estimated using NRC (2001) were as expected: AMP_AE and DMP_AE diets had equivalent $\mathrm{NE}_{\mathrm{L}}$, whereas DMP_DE and DMP_EE diets had, respectively, lower and higher $\mathrm{NE}_{\mathrm{L}}$ concentration than the AMP_AE diet. The concentration of $\mathrm{NE}_{\mathrm{L}}$ in DMP_AE and DMP_EE diets was adjusted with Ca salts of long-chain fatty acids, whereas chopped wheat straw was used for energy dilution in the DMP_DE diet. Consequently, DMP_DE diet had greater concentrations of aNDF and ADF, and lower NFC concentration compared with AMP_AE diet. In contrast, due to a greater proportion of corn starch, DMP_AE and DMP_EE diets had lower concentrations of aNDF and $\mathrm{ADF}$, and higher NFC concentration than the AMP_AE diet.

Protein fractions, MP, AA, and energy balance were calculated according to NRC (2001). Requirements were based on DMI, BW, milk yield, and milk composition of cows receiving AMP_AE treatment, assuming that these reflected the potential of the cows. Protein and energy supplies were based on observations for each treatment (i.e., individual intake; Table 3). Assuming that the milk production potential of the DMP-fed cows was similar to that of the AMP_AE-fed cows, DMP_DE, DMP_AE, and DMP_EE diets provided, respectively, 84,87 , and $87 \%$ of MP requirement. The AMP_AE diet slightly supplied $(3 \%)$ above the MP requirement. The DMP_DE, DMP_AE and DMP_EE diets, respectively, supplied 94, 101, and $107 \%$ of $\mathrm{NE}_{\mathrm{L}}$ requirements, whereas the AMP_AE diet supplied $108 \%$ of $\mathrm{NE}_{\mathrm{L}}$ requirements. There was no estimated RDP deficiency for cows fed AMP_AE, but cows fed DMP_DE, DMP_AE, and DMP_EE diets had estimated RDP deficiencies of 15,10 , and $7 \%$, respectively. The RDP deficiencies in DMP diets occurred despite the inclusion of urea into these diets. According to estimated requirements in $\mathrm{g} / \mathrm{d}$, AA balance was adequate for dHis, dLys, and dMet in AMP_AE-fed cows. In DMP_DE-, DMP_AE-, and DMP_EE-fed cows, AA deficiencies were estimated at 8,7 , and $5 \%$ for dHis, 3,1 , and $0 \%$ for dLys, and 7, 3, and $5 \%$ for dMet, respectively. Because of the lower DMI in deficient-MP compared with the adequate-MP diet (only numerical for DMP_AE and DMP_EE diets), only DMP_EE-fed cows had a similar supply and positive $\mathrm{NE}_{\mathrm{L}}$ balance than that of AMP_AE-fed cows $(+2.8 \mathrm{Mcal} / \mathrm{d})$. Lower than expected DMI, and lower than expected CP concentration of ingredients could explain the differences between estimations from NRC (2001) and cow responses, which resulted in lower than predicted MP, RDP, RUP, and EAA (dHis, dLys, and dMet) balances.

\section{Animal Performance}

As compared with cows receiving AMP_AE, the DMI of cows fed DMP_AE and DMP_EE was not statistically different but was reduced for cows fed DMP_DE (Table 4). Cows fed the DMP diets had, however, a similar DMI. The decrease observed with the DMP_DE 
Table 2. Ingredients and chemical composition of experimental diets

\begin{tabular}{|c|c|c|c|c|}
\hline \multirow[b]{2}{*}{ Item } & \multicolumn{4}{|c|}{$\operatorname{Diet}^{1}$} \\
\hline & AMP_AE & DMP_DE & DMP_AE & DMP_EE \\
\hline \multicolumn{5}{|l|}{ Ingredient, $\%$ of $\mathrm{DM}$} \\
\hline Alfalfa silage & 51.0 & 51.0 & 51.0 & 51.0 \\
\hline Corn silage & 17.0 & 17.0 & 17.0 & 17.0 \\
\hline Ground corn & 20.3 & 8.1 & 12.6 & 9.7 \\
\hline Corn starch & 0.0 & 9.8 & 13.6 & 13.6 \\
\hline Wheat straw & 0.0 & 8.9 & 0.0 & 0.0 \\
\hline Soybean meal & 7.6 & 0.0 & 0.0 & 0.0 \\
\hline Megalac $^{2}$ & 0.7 & 0.0 & 0.8 & 3.5 \\
\hline Blood meal $^{3}$ & 1.1 & 2.6 & 2.4 & 2.4 \\
\hline Mineral and vitamin $\operatorname{mix}^{4}$ & 1.8 & 1.8 & 1.8 & 1.8 \\
\hline Water & 0.5 & 0.8 & 0.8 & 0.9 \\
\hline Urea & 0.0 & 0.2 & 0.3 & 0.4 \\
\hline Rumen-protected Lys ${ }^{5}$ & 0.3 & 0.4 & 0.4 & 0.3 \\
\hline Rumen-protected Met ${ }^{6}$ & 0.1 & 0.1 & 0.1 & 0.1 \\
\hline \multicolumn{5}{|l|}{ Analyzed composition $^{7}$} \\
\hline $\mathrm{DM}(\%$ as fed $)$ & 46.5 & 47.6 & 47.5 & 47.6 \\
\hline $\mathrm{OM}$ & 91.3 & 91.9 & 92.0 & 91.6 \\
\hline $\mathrm{CP}$ & 16.2 & 14.1 & 14.3 & 14.3 \\
\hline $\mathrm{aNDF}^{8}$ & 36.6 & 40.5 & 33.9 & 34.0 \\
\hline $\mathrm{ADF}$ & 28.9 & 31.6 & 26.8 & 26.8 \\
\hline ADL & 6.0 & 6.4 & 5.5 & 5.4 \\
\hline IVTD $^{9}$ & 81.9 & 77.8 & 82.2 & 82.6 \\
\hline $48-\mathrm{NDFd}^{10}(\%$ of aNDF $)$ & 50.8 & 45.6 & 48.1 & 49.3 \\
\hline $\mathrm{uNDF}_{240}$ & 16.3 & 19.3 & 15.7 & 15.7 \\
\hline Ether extract $^{12}$ & 3.3 & 2.4 & 3.2 & 5.3 \\
\hline $\mathrm{Ca}$ & 1.14 & 1.03 & 1.09 & 1.22 \\
\hline $\mathrm{P}$ & 0.40 & 0.31 & 0.33 & 0.33 \\
\hline \multicolumn{5}{|l|}{ Fatty acids, $\mathrm{mg} / \mathrm{g}$ of DM } \\
\hline $12: 0$ & 0.11 & 0.10 & 0.11 & 0.22 \\
\hline 14:0 & 0.23 & 0.20 & 0.24 & 0.42 \\
\hline $14: 1$ & 0.05 & 0.05 & 0.06 & 0.06 \\
\hline $16: 0$ & 5.88 & 3.48 & 5.48 & 11.86 \\
\hline $16: 1$ & 0.06 & 0.06 & 0.07 & 0.07 \\
\hline $18: 0$ & 0.81 & 0.56 & 0.77 & 1.39 \\
\hline cis-9 18:1 & 3.99 & 1.65 & 3.35 & 8.13 \\
\hline cis-11 18:1 & 0.15 & 0.10 & 0.16 & 0.25 \\
\hline n-6 18:2 & 6.96 & 4.46 & 5.50 & 6.37 \\
\hline n-3 18:3 & 3.73 & 3.58 & 3.71 & 3.71 \\
\hline $20: 0$ & 0.20 & 0.17 & 0.18 & 0.23 \\
\hline Total & 22.17 & 14.40 & 19.63 & 32.72 \\
\hline \multicolumn{5}{|l|}{ Calculated composition $^{7,13}$} \\
\hline RDP & 10.5 & 8.9 & 9.2 & 9.4 \\
\hline RUP & 6.0 & 5.4 & 5.1 & 5.0 \\
\hline $\mathrm{NE}_{\mathrm{L}}, \mathrm{Mcal} / \mathrm{kg}$ of DM & 1.53 & 1.44 & 1.51 & 1.59 \\
\hline NFC & 43.1 & 41.0 & 47.3 & 44.9 \\
\hline
\end{tabular}

${ }^{1}$ Diets formulated to meet: $100 \%$ of MP and energy requirement $=$ AMP_AE; $90 \%$ of MP requirement and $94 \%$ of energy requirement $=$ DMP_DE; $90 \%$ of MP requirement and $99 \%$ of energy requirement $=$ DMP_AE; $90 \%$ of MP requirement and $104 \%$ of energy requirement = DMP_EE.

${ }^{2}$ Megalac (Church and Dwight Co. Inc.).

${ }^{3}$ Agribrands Purina Canada Inc.

${ }^{4}$ Contained (per $\mathrm{kg}$ of DM): $\mathrm{Ca}=131.6 \mathrm{~g} / \mathrm{kg} ; \mathrm{P}=84.6 \mathrm{~g} / \mathrm{kg} ; \mathrm{Mg}=90 \mathrm{~g} / \mathrm{kg} ; \mathrm{Zn}=2,820 \mathrm{~g} / \mathrm{kg} ; \mathrm{Cu}=0.564 \mathrm{~g} / \mathrm{kg}$; $\mathrm{Mn}=1,880 \mathrm{~g} / \mathrm{kg}$; vitamin $\mathrm{A}=282 \mathrm{kIU} / \mathrm{kg}$; vitamin $\mathrm{D}=94 \mathrm{kIU} / \mathrm{kg}$; vitamin $\mathrm{E}=1,410 \mathrm{kIU} / \mathrm{kg}$.

${ }^{5}$ AjiPro-L 3rd Generation: $30 \%$ bioavailability $=41 \%$ Lys, RUP: $80.5 \%$, intestinal digestibility: $90.5 \%$, from feed manufacturer Ajinomoto Heartland Inc.

${ }^{6}$ Smartamine M: $71 \%$ bioavailability $=75 \%$ Met, RUP: $100 \%$, intestinal digestibility: $95 \%$, from feed manufacturer Adisseo NA.

${ }^{7}$ Percent of DM, unless specified.

${ }^{8}$ Neutral detergent fiber assayed with a heat-stable amylase and sodium sulfite.

${ }^{9}$ In vitro true digestibility of DM.

${ }^{10} \mathrm{NDF}$ digestibility.

${ }^{11}$ Undigested NDF estimated via 240 -h in vitro fermentation.

${ }^{12}$ Calculated from the ether extract concentration of each ingredient.

${ }^{13}$ Estimated based on NRC (2001). 
Table 3. Estimated protein, digestible EAA (dEAA), and energy balance ${ }^{1}$ in dairy cows

\begin{tabular}{|c|c|c|c|c|}
\hline \multirow[b]{2}{*}{ Item } & \multicolumn{4}{|c|}{$\operatorname{Diet}^{2}$} \\
\hline & $\mathrm{AMP} \_\mathrm{AE}$ & DMP_DE & DMP_AE & DMP_EE \\
\hline \multicolumn{5}{|c|}{ Protein and dEAA balance, ${ }^{3} \mathrm{~g} / \mathrm{d}$} \\
\hline Requirements ${ }^{4}$ & 2,582 & 2,582 & 2,582 & 2,582 \\
\hline Supply ${ }^{5}$ & 2,666 & 2,180 & 2,234 & 2,255 \\
\hline Balance & 84 & -402 & -348 & -327 \\
\hline \multicolumn{5}{|l|}{ RDP and RUP } \\
\hline RDP supply ${ }^{5}$ & 2,751 & 2,135 & 2,263 & 2,341 \\
\hline RDP balance ${ }^{4}$ & 242 & -374 & -246 & -168 \\
\hline RUP supply ${ }^{5}$ & 1,543 & 1,278 & 1,245 & 1,222 \\
\hline RUP balance ${ }^{4}$ & 110 & -155 & -188 & -211 \\
\hline \multicolumn{5}{|l|}{ dHis } \\
\hline Requirements ${ }^{4,6}$ & 61 & 61 & 61 & 61 \\
\hline Supply ${ }^{5}$ & 61 & 56 & 57 & 58 \\
\hline Balance & 0 & -5 & -4 & -3 \\
\hline \multicolumn{5}{|l|}{ dLys } \\
\hline Requirements ${ }^{4,6}$ & 179 & 179 & 179 & 179 \\
\hline Supply ${ }^{5}$ & 195 & 174 & 178 & 180 \\
\hline Balance & 16 & -5 & -1 & 1 \\
\hline \multicolumn{5}{|l|}{ dMet } \\
\hline Requirements ${ }^{4,6}$ & 61 & 61 & 61 & 61 \\
\hline Supply ${ }^{5}$ & 64 & 57 & 59 & 58 \\
\hline Balance & 3 & -4 & -2 & -3 \\
\hline \multicolumn{5}{|c|}{ Other dEAA supply ${ }^{5}$} \\
\hline $\mathrm{dArg}$ & 122 & 94 & 98 & 99 \\
\hline dIle & 124 & 95 & 99 & 101 \\
\hline dLeu & 232 & 195 & 202 & 204 \\
\hline dPhe & 134 & 112 & 115 & 116 \\
\hline dThr & 128 & 106 & 110 & 112 \\
\hline dVal & 149 & 129 & 133 & 136 \\
\hline \multicolumn{5}{|c|}{ Energy balance, ${ }^{3} \mathrm{Mcal} / \mathrm{d}$} \\
\hline \multicolumn{5}{|c|}{$\mathrm{NE}_{\mathrm{L}}$} \\
\hline Requirements $^{4}$ & 37.1 & 37.1 & 37.1 & 37.1 \\
\hline Supply ${ }^{5}$ & 39.9 & 34.8 & 37.6 & 39.7 \\
\hline Balance & 2.8 & -2.3 & 0.5 & 2.6 \\
\hline
\end{tabular}

${ }^{1}$ All values estimated using NRC (2001).

${ }^{2}$ Diets formulated to meet: 100\% of MP and energy requirement = AMP_AE; $90 \%$ of MP requirement and $94 \%$ of energy requirement $=$ DMP_DE; $90 \%$ of MP requirement and 99\% of energy requirement = DMP_AE; $90 \%$ of MP requirement and $104 \%$ of energy requirement = DMP_EE.

${ }^{3}$ Due to rounding, balance may not exactly match requirements and supply.

${ }^{4}$ Requirements based on DMI, BW, milk yield, and milk composition of cows receiving AMP_AE treatment, assuming that these reflected the potential of the cows.

${ }^{5}$ Supply based on observations within each treatment.

${ }^{6}$ Requirements of digestible His (dHis), digestible Lys (dLys), and digestible Met (dMet) were calculated as $2.38 \%, 6.95 \%$, and $2.38 \%$ of the MP requirement, respectively.

diet is probably related to its high aNDF and ADF concentrations. Indeed, forage NDF is a key driver of DMI (Sauvant et al., 2014). In addition, a low protein supplementation has been reported to decrease feed intake (Vérité and Delaby, 2000; Huhtanen and Hetta, 2012; Owens et al., 2014). A low protein supply can result in a RDP deficiency, as observed in the DMP diets. This deficiency could have depressed ruminal functions, which in turn could lower DMI (Allen, 2000). This hypothesis is supported by the tendency for a decreased apparent digestibility of CP (Table 5) as well as the decreased estimates of microbial $\mathrm{N}$ flow with the DMP_DE diet and intermediate values observed with the 2 other DMP diets (Table 6), as compared with the AMP_AE diet. Although in our study no effect of treatment on NDF digestibility was observed, several studies have reported a significant or numerical decrease of total-tract NDF digestibility and DMI with RDP deficient diets (Lee et al., 2011, 2012a,c). Two of these studies also noted a trend or a numerical decrease in urinary PD excretion (Lee et al., 2012b,c), suggesting a decreased microbial synthesis. On the other hand, Boucher et al. (2007) did not notice an increase in DMI or fiber digestibility when RDP supply was above re- 
Table 4. Effect of MP and energy supplies on DMI, milk yield, milk composition, and BW in dairy cows

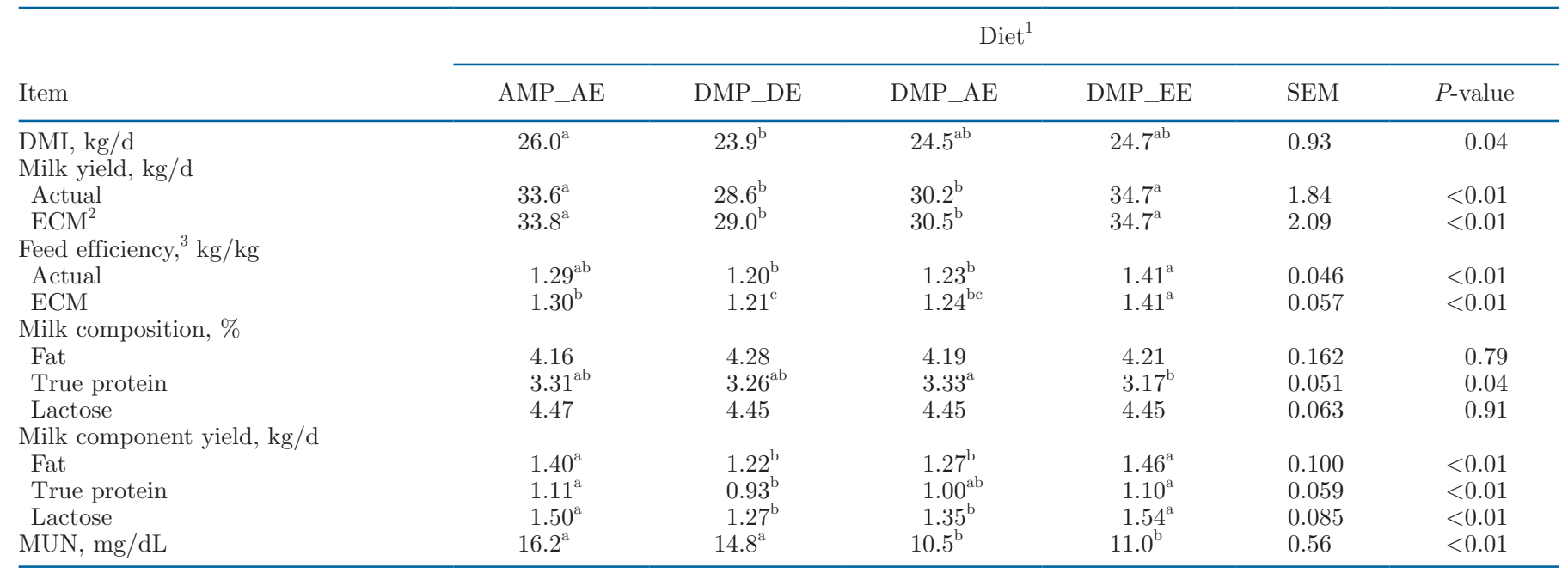

${ }^{\mathrm{a}-\mathrm{c}}$ Within a row, means without a common superscript letter differ $(P \leq 0.05)$.

${ }^{1}$ Diets formulated to meet: $100 \%$ of MP and energy requirement $=$ AMP_AE; $90 \%$ of MP requirement and $94 \%$ of energy requirement $=$ DMP DE; $90 \%$ of MP requirement and 99\% of energy requirement $=$ DMP_AE; 90\% of MP requirement and 104\% of energy requirement $=$ DMP_EE. ${ }^{2}$ Energy-corrected milk $(\mathrm{kg} / \mathrm{d})=[23.8 \times($ protein yield in $\mathrm{kg} / \mathrm{d})]+[38.9 \times($ fat yield in $\mathrm{kg} / \mathrm{d})]+[16.3 \times($ lactose yield in $\mathrm{kg} / \mathrm{d})] \div 3.14(\mathrm{Madsen}$ et al., 2008).

${ }^{3}$ Milk yield/DMI.

quirements. However, diets fed in this latter study had a low proportion of forages. As suggested by Giallongo et al. (2016), a high proportion of forage seems to exacerbate negative effects of RDP-deficient diets. In addition to its effect on rumen function, additional protein supply may have a metabolic effect in stimulating DMI. Indeed, Martineau et al. (2016) reported that postrumen casein infusion affected DMI differently depending on MP balance in dairy cows. They observed that for cows with a negative MP balance, postrumen casein infusion increased DMI, whereas it decreased DMI for cows with a positive MP balance.

Compared with AMP_AE, milk yields (actual and ECM) as well as milk fat and lactose yields decreased in the DMP_DE- and DMP_AE-fed cows, but not in the DMP_EE-fed cows. Only DMP_DE cows had a lower milk true protein yield than that of AMP_AE cows and DMP_EE cows, with DMP_AE cows having an intermediate value. The $\mathrm{NE}_{\mathrm{L}}$ supply did not differ between AMP_AE and DMP_EE; in DMP_EE,

Table 5. Effect of MP and energy supplies on intake and total-tract apparent digestibility of nutrients in dairy cows

\begin{tabular}{lccccc}
\hline & \multicolumn{3}{c}{ Diet $^{1}$} \\
\cline { 2 - 4 } Item & AMP_AE & DMP_DE & DMP_AE & DMP_EE & SEM \\
\hline Nutrient intake, kg/d & & & & \\
DM & $26.0^{\mathrm{a}}$ & $23.9^{\mathrm{b}}$ & $24.5^{\mathrm{ab}}$ & $24.7^{\mathrm{ab}}$ & 0.93 \\
OM & 23.7 & 22.0 & 22.6 & 22.7 & 0.86 \\
aNDF & $9.59^{\mathrm{a}}$ & $9.65^{\mathrm{a}}$ & $8.36^{\mathrm{b}}$ & $8.51^{\mathrm{b}}$ & 0.323 \\
ADF & $7.55^{\mathrm{a}}$ & $7.53^{\mathrm{a}}$ & $6.58^{\mathrm{b}}$ & $6.72^{\mathrm{b}}$ & 0.236 \\
CP & $4.21^{\mathrm{a}}$ & $3.40^{\mathrm{b}}$ & $3.52^{\mathrm{b}}$ & $3.49^{\mathrm{b}}$ & 0.139 \\
Apparent digestibility, & & & $<0.01$ & $<0.01$ \\
DM & $64.8^{\mathrm{ab}}$ & $61.8^{\mathrm{b}}$ & $65.7^{\mathrm{a}}$ & $65.2^{\mathrm{a}}$ & 0.75 \\
OM & $65.9^{\mathrm{ab}}$ & $63.3^{\mathrm{b}}$ & $67.2^{\mathrm{a}}$ & $67.1^{\mathrm{a}}$ & 0.66 \\
aNDF & 49.2 & 45.2 & 46.5 & 46.6 & 0.01 \\
ADF & 53.0 & 48.3 & 50.6 & 50.0 & 1.73 \\
CP & 65.8 & 61.7 & 62.7 & 64.0 & 0.01 \\
\hline
\end{tabular}

${ }^{\mathrm{a}, \mathrm{b}}$ Within a row, means without a common superscript letter differ $(P \leq 0.05)$.

${ }^{1}$ Diets formulated to meet: $100 \%$ of MP and energy requirement $=$ AMP_AE; $90 \%$ of MP requirement and $94 \%$ of energy requirement $=$ DMP $\_$ DE; $90 \%$ of MP requirement and 99\% of energy requirement = DMP_AE; $90 \%$ of MP requirement and 104\% of energy requirement = DMP_EE. ${ }^{2}$ Neutral detergent fiber assayed with a heat-stable amylase and sodium sulfite. 
Table 6. Effect of MP and energy supplies on $\mathrm{N}$ input and output, and urinary purine derivative (PD) excretion in dairy cows

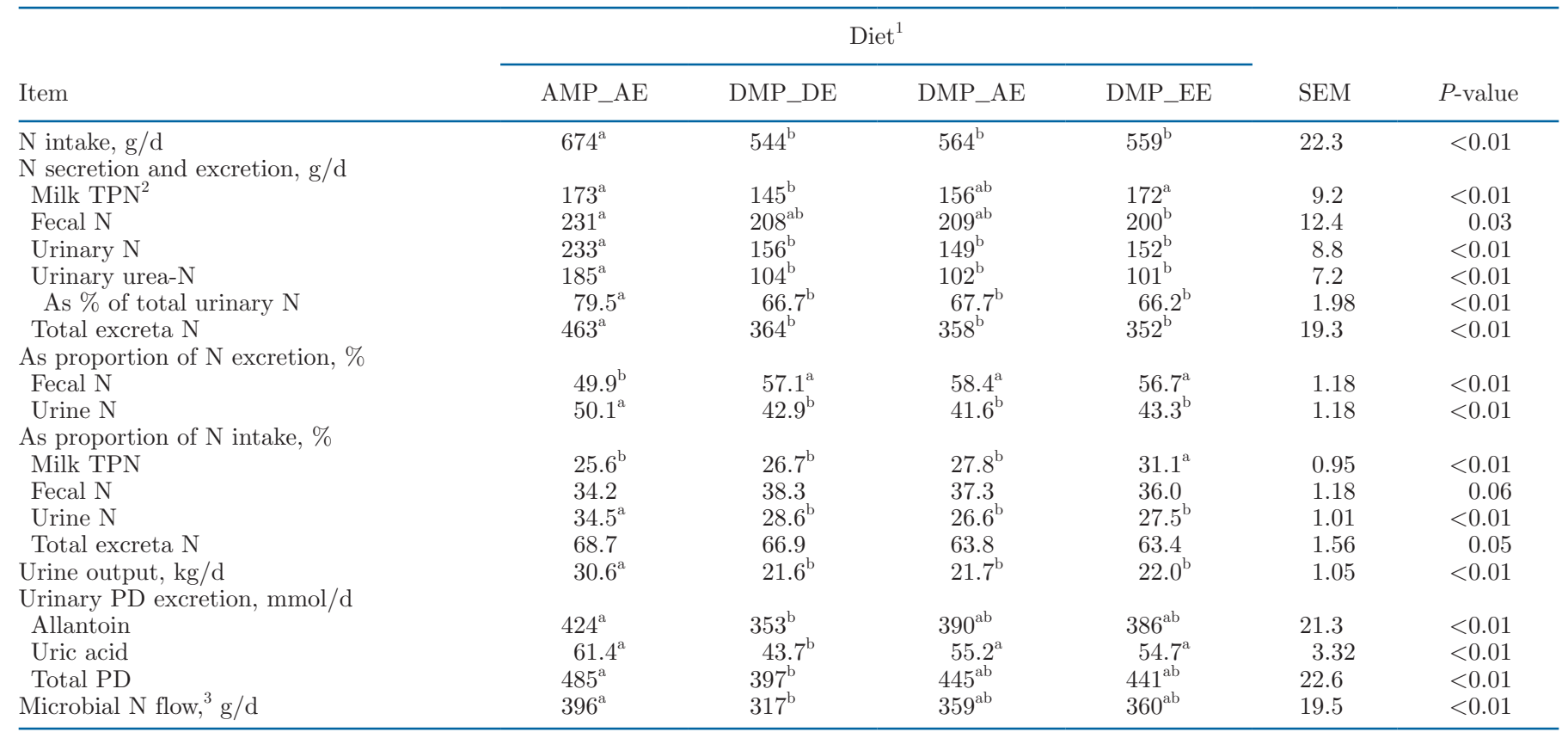

${ }^{\mathrm{a}, \mathrm{b}}$ Within a row, means without a common superscript letter differ $(P \leq 0.05)$.

${ }^{1}$ Diets formulated to meet: $100 \%$ of MP and energy requirement $=$ AMP_AE; $90 \%$ of MP requirement and $94 \%$ of energy requirement $=$ DMP $\_$ DE; $90 \%$ of MP requirement and $99 \%$ of energy requirement $=$ DMP_AE; $90 \%$ of MP requirement and $104 \%$ of energy requirement $=$ DMP_EE. ${ }^{2}$ Milk true protein N (milk true protein $\div 6.38$ ).

${ }^{3}$ Estimated based on urinary PD excretion (Chen and Gomes, 1992).

however, MP supply was $13 \%$ lower than predicted requirements, but dHis and dMet were only $5 \%$ below requirements whereas dLys met requirements. Therefore, despite a lower MP supply, with supplies of dHis, dLys, and dMet at or close to the requirements, MPY was maintained when the energy supply was equivalent to the level of the AMP_AE diet. This supports the hypothesis that the requirements of dairy cows are associated with the EAA and not the MP supply per se. As demonstrated by Lee et al. (2012c), decreasing MP supply at levels below predicted requirements does not negatively affect milk yield and MPY when His, Lys, and Met supplies are adequate, as long as energy intake is sufficient. In contrast, Giallongo et al. (2016) failed to increase milk yield with dietary supplementation of a MP-deficient diet with the combination of RP-His, RP-Lys, and RP-Met, but did increase MPY with supplementation of the combined 3 RP AA. Our results are consistent with those of Omphalius et al. (2019b), where MPY was dependent on both energy and EAA supplies. Our observations also suggest that MPY does not rely solely on MP supply: indeed, we did not observe that a decrease in MP supply reduced MPY, as long as the supplies of energy and of His, Lys, and Met did not decrease substantially below requirements. The most limiting EAA with typical North
American dairy diets are often considered to be His, Lys, and Met (Schwab and Broderick, 2017). Indeed, Robinson (2010) observed in his meta-analysis that a RP-Lys and Met combination increased milk and milk energy yields, milk protein concentration, feed use efficiency, and $\mathrm{N}$ use efficiency. With DMP diets based on corn silage and alfalfa fed to high-producing dairy cows, a combination of rumen-protected His, Lys, and Met was sufficient to maintain milk and milk component yields to the level observed with the MP-adequate diet (Lee et al., 2012c). In line with other observations (Lee et al., 2012c; Giallongo et al., 2015, 2016), MP allowable milk from the NRC (2001) model was severely underestimated in DMP diets $(-2.1,-2.9$, and $-7.0 \mathrm{~kg}$ of milk/d, for DMP_DE, DMP_AE, and DMP_EE, respectively), indicating that the use of a fixed efficiency of utilization of MP does not fit reality and needs revision (Doepel et al., 2004). Efficiency of utilization of MP will be discussed in detail in a following section. Actual feed efficiency was higher for cows fed DMP_EE diet than for cows fed DMP_DE and DMP_AE diets, whereas AMP_AE-fed cows had an intermediate value. The ECM feed efficiency was greater for cows receiving DMP_EE diet in comparison with cows receiving other treatments. The high energy concentration in DMP_EE diet explains this observation. 
Fat and lactose concentrations in milk were not affected by dietary treatments (Table 4). However, probably due to a dilution effect, true protein concentration in milk from DMP_EE-fed cows was lower from that of DMP_AE-fed cows, whereas AMP_AE- and DMP_DE-fed cows had intermediate values. The MUN concentration was lower when cows were fed DMP_AE or DMP_EE diets in comparison with AMP_AE. Despite a reduced $\mathrm{N}$ intake compared with AMP_AE, the DMP_DE diet did not allow a reduction in MUN, probably because of a lack in fermentable energy in the rumen as indicated by the lower PD urinary excretion, or a lack of digestible energy, which impaired the utilization of absorbed AA.

\section{Apparent Digestibility, N Input and Output, MP, and EAA Efficiency of Utilization}

Despite the effect of dietary treatments on DMI, only a trend was observed for intake of OM (Table 5). Intakes of fibers (i.e., aNDF and ADF) were lower when cows consumed DMP_AE and DMP_EE diets than when cows received AMP_AE and DMP_DE diets. As expected, CP intake was lower when cows were fed DMP diets compared with AMP_AE diet.

Total-tract apparent digestibilities of aNDF and ADF were not significantly affected by dietary treatments. However, we noticed a tendency in apparent digestibility of $\mathrm{CP}$ among diets. The amplitude of the RDP deficiency in DMP diets was probably too small to have a significant effect on apparent digestibility of aNDF and ADF, even though it seems to have affected microbial $\mathrm{N}$ flow. Also, a lack of statistical power may have prevented the observation of a significant effect since standard deviation relative to mean values were greater for aNDF and ADF digestibilities compared with other nutrients. Numerically, aNDF and ADF apparent digestibilities are lower with DMP diets compared with AMP_AE-fed cows, which is consistent with estimated microbial $\mathrm{N}$ flow. Moreover, predicted NDF digestibilities (NRC, 2001) changed little among treatments (maximum variation of 0.7 unit of \%). In accordance with concentrations of aNDF, ADF, and NFC in diets, apparent digestibilities of DM and OM were greater with DMP_AE and DMP_EE diets when compared with DMP_DE diet, whereas AMP_AE had an intermediate value.

Intake of $\mathrm{N}$ was reduced with DMP diets (Table 6 ), similarly to $\mathrm{CP}$ intake described earlier. Fecal N excretion was reduced when cows were fed DMP_EE compared with AMP_AE; cows fed DMP_DE and DMP_AE diets had intermediate fecal $\mathrm{N}$ excretion. Fecal $\mathrm{N}$ as proportion of $\mathrm{N}$ intake, however, was not affected by dietary treatments but tended to be higher in DMP diets. Urinary $\mathrm{N}$ excretion decreased by an average of $35 \%$ when cows were fed the DMP diets compared with AMP_AE (Table 6). The DMP diets also reduced urinary $\mathrm{N}$ excretion in proportion of $\mathrm{N}$ intake. Similarly, excretion of urinary urea-N was reduced by an average of $45 \%$ with DMP diets and the DMP diets reduced urinary urea-N excretion as a percentage of urinary $\mathrm{N}$ as well. These results have important implications, because $\mathrm{N}$ from urinary urea is rapidly transformed into ammonium, then volatilized as ammonia into the environment (Hristov et al., 2011). Ammonia is a molecule causing several environmental and health problems (Hristov et al., 2011). The positive effect of decreasing dietary CP concentration on ammonia emissions from manure is well documented (Külling et al., 2001; Lee et al., 2012a; Hristov et al., 2015). Some authors also suggested that a reduced dietary CP concentration could have mitigating effects on emission of nitrous oxide, a greenhouse gas (Külling et al., 2001; Lee et al., 2012a). Moreover, ammonia and nitrous oxide emissions represent a loss of fertilizing power of manure (Hristov et al., 2011). Total $\mathrm{N}$ in excreta, on a daily basis, decreased by an average of $23 \%$ with the DMP diets, and as proportion of $\mathrm{N}$ intake, total $\mathrm{N}$ in excreta tended to be lower with the DMP diets. When decreasing MP supply but balancing dairy diets for His, Lys, and Met, Lee et al. (2012c) reported a decreased urinary excretion of N and urea-N. Moreover, Giallongo et al. (2015) also reported a significant decrease in excretion of $\mathrm{N}$ and urea- $\mathrm{N}$ from urine when reducing MP supply below estimated dairy cow requirements. However, these authors did not observe a significant reduction in total $\mathrm{N}$ excretion, probably because of a limited effect on total $\mathrm{N}$ intake and no reduction of fecal $N$ with decreased MP supply.

Daily urine output was lower when cows were fed the DMP diets $(-29 \%)$. Urinary excretions of allantoin, uric acid, and total PD were affected by treatments. Whereas feeding DMP_DE resulted in a reduction of these compounds in comparison with AMP_AE, feeding DMP_AE or DMP_EE did not result in significant reductions. Other authors who have lowered the RDP supply below requirements have also observed a tendency for a reduction or a numerical decrease in urinary PD excretion (Gressley and Armentano, 2007; Lee et al., 2012b,c), probably related to a depression of ruminal functions. Therefore, when compared with the other diets, only DMP_DE diet reduced microbial $\mathrm{N}$ flow estimated from urinary PD excretion. As discussed earlier, microbial $\mathrm{N}$ flow values of cows receiving DMP_AE or DMP_EE were intermediate: lower than those of AMP_AE-fed cows but higher than DMP_DE- 
Table 7. Effect of MP and energy supplies on the estimated efficiency ${ }^{1}$ of use of individual EAA and MP in dairy cows

\begin{tabular}{lccccrr}
\hline \multicolumn{5}{c}{ Diet $^{2}$} & & \\
Item & \multirow{2}{*}{ AMP_AE } & DMP_DE & DMP_AE & DMP_EE & SEM & $P$-value \\
\cline { 2 - 5 } & $0.62^{\mathrm{c}}$ & $0.68^{\mathrm{b}}$ & $0.69^{\mathrm{b}}$ & $0.74^{\mathrm{a}}$ & 0.016 & $<0.01$ \\
MP & $0.74^{\mathrm{ab}}$ & $0.71^{\mathrm{b}}$ & $0.73^{\mathrm{ab}}$ & $0.77^{\mathrm{a}}$ & 0.018 & 0.02 \\
His & $0.66^{\mathrm{c}}$ & $0.75^{\mathrm{b}}$ & $0.75^{\mathrm{b}}$ & $0.81^{\mathrm{a}}$ & 0.020 & $<0.01$ \\
Ile & $0.64^{\mathrm{b}}$ & $0.66^{\mathrm{b}}$ & $0.67^{\mathrm{b}}$ & $0.72^{\mathrm{a}}$ & 0.018 & $<0.01$ \\
Leu & $0.63^{\mathrm{b}}$ & $0.61^{\mathrm{b}}$ & $0.62^{\mathrm{b}}$ & $0.67^{\mathrm{a}}$ & 0.017 & $<0.01$ \\
Lys & $0.61^{\mathrm{b}}$ & $0.58^{\mathrm{b}}$ & $0.60^{\mathrm{b}}$ & $0.66^{\mathrm{a}}$ & 0.018 & $<0.01$ \\
Met & $0.56^{\mathrm{b}}$ & $0.59^{\mathrm{b}}$ & $0.60^{\mathrm{b}}$ & $0.64^{\mathrm{a}}$ & 0.015 & $<0.01$ \\
Phe & $0.59^{\mathrm{c}}$ & $0.63^{\mathrm{b}}$ & $0.63^{\mathrm{ab}}$ & $0.67^{\mathrm{a}}$ & 0.015 & $<0.01$ \\
Thr & $0.65^{\mathrm{b}}$ & $0.65^{\mathrm{b}}$ & $0.66^{\mathrm{ab}}$ & $0.70^{\mathrm{a}}$ & 0.017 & $<0.01$ \\
Val & & & & & & \\
\hline
\end{tabular}

${ }^{\mathrm{a}-\mathrm{c}}$ Within a row, means without a common superscript letter differ $(P \leq 0.05)$.

${ }^{1}$ Efficiency of MP and individual AA was calculated according to Omphalius et al. (2020): (milk protein + metabolic fecal protein + scurf)/(supply - endogenous urinary loss).

${ }^{2}$ Diets formulated to meet: 100\% of MP and energy requirement = AMP_AE; $90 \%$ of MP requirement and $94 \%$ of energy requirement = DMP_DE; $90 \%$ of MP requirement and 99\% of energy requirement = DMP_AE; $90 \%$ of MP requirement and 104\% of energy requirement $=$ DMP_EE.

fed cows. Microbial N flow calculated based on PD excretion were on average $157 \mathrm{~g} / \mathrm{d}$ greater than estimates from NRC (2001), but trends in changes were similar to estimations.

As a proportion of $\mathrm{N}$ intake, $\mathrm{N}$ in milk reflecting milk $\mathrm{N}$ efficiency was greater when cows were fed DMP_EE diet compared with all other diets (Table 6). Based on a meta-analysis, $\mathrm{CP}$ concentration and intake have been determined as the most important dietary factors influencing milk $\mathrm{N}$ efficiency (Huhtanen and Hristov, 2009). In addition, it is recognized that increasing energy supply increases milk N efficiency (NorFor, 2011; INRA 2018). However, the effect of the type of energy on milk $\mathrm{N}$ efficiency is not yet completely understood (Nichols et al., 2018, 2019). In a study of Omphalius et al. (2020), higher energy intake had increased MPY through increased mammary use of Group 2 EAA (Ile, Leu, Lys, and Val) taken up by the mammary gland to support MPY and reduced catabolism of EAA, which allowed the increment of milk $\mathrm{N}$ efficiency at a similar EAA supply. In contrast, when $\mathrm{N}$ intake was increased, MPY increased to a lesser extent than $\mathrm{N}$ intake (Omphalius et al., 2020), reducing milk $\mathrm{N}$ efficiency. The improved milk $\mathrm{N}$ efficiency when cows were fed the DMP_EE diet suggests that the sustainability of dairy farms may be improved when reducing MP supply at a constant $\mathrm{NE}_{\mathrm{L}}$ supply, given the potential decreased usage of protein supplement for similar lactation performance.

Although milk $\mathrm{N}$ efficiency is interesting to give a global picture of the partition of $\mathrm{N}$ to milk at the whole body level, more detailed efficiency of utilization of digested protein and absorbed EAA is needed to help improving formulation of dairy rations. Effi- ciency of utilization of MP and EAA are presented in Table 7. Compared with AMP_AE-fed cows, feeding DMP_EE diet increased whole-body efficiencies of MP and EAA, except for His (Table 7); this is explained by the fact that, in the latter diet, the supply of MP and EAA decreased but MPY did not. At the moment there are no reference values that we should target for this relatively new concept of EAA efficiency, but we can compare our values with means of a metaanalysis reported by Lapierre et al. (2020). The Lys and Met efficiencies were relatively low, and even in the DMP_EE diet, they did not increase above the mean values of 0.67 and 0.71 , respectively, reported by Lapierre et al. (2020). This would indicate that their supplies were sufficient. The His efficiency was relatively high especially for DMP_EE-fed cows, but still slightly lower than the mean of 0.78 (Lapierre et al., 2020). Lapierre et al. (2021) recently reported that an efficiency of 0.77 should be targeted for His, above which His supply might be in shortage. Compared with the 0.61 mean reported by Lapierre et al. (2020), Ile efficiency was high, especially in the DMP diets: this indicates that we need to pay attention to all EAA when feeding low-MP diets. Limiting EAA may depend on the ingredients composing the diet. The effect of a higher energy supply on the efficiency of EAA in a DMP diet compared with an adequate energy and MP diet remains, unfortunately, an unanswered question. Although it was one of the objectives of the study, due to the numerically lower DMI in DMP_EE- than AMP_AE-fed cows, it could not be assessed. Maintaining a high DMI with a low-MP supply seems to be a challenge, hence the importance of having a diet that is concentrated in energy. 
Table 8. Effect of MP and energy supplies on plasma metabolite concentrations in dairy cows

\begin{tabular}{|c|c|c|c|c|c|c|}
\hline \multirow[b]{2}{*}{ Item } & \multicolumn{4}{|c|}{$\operatorname{Diet}^{1}$} & \multirow[b]{2}{*}{ SEM } & \multirow[b]{2}{*}{$P$-value } \\
\hline & AMP_AE & DMP_DE & $\mathrm{DMP} \_\mathrm{AE}$ & DMP_EE & & \\
\hline Glucose, $\mathrm{m} M$ & 3.54 & 3.41 & 3.62 & 3.44 & 0.087 & 0.34 \\
\hline NEFA, ${ }^{2} \mu M$ & 98.5 & 164.5 & 134.8 & 153.3 & 26.16 & 0.33 \\
\hline Urea $\mathrm{N}, \mathrm{m} M$ & $12.1^{\mathrm{a}}$ & $11.0^{\mathrm{ab}}$ & $8.3^{\mathrm{c}}$ & $9.0^{\mathrm{bc}}$ & 0.64 & $<0.01$ \\
\hline
\end{tabular}

\section{Plasma Metabolites and AA Concentrations, and Milk Fatty Acid Composition}

Concentrations of plasma glucose and NEFA were not affected by treatments (Table 8). In previous experiments, MP deficiency did not affect plasma glucose concentration (e.g., Giallongo et al., 2015, 2016). However, Urdl et al. (2015) reported a positive correlation between energy balance and plasma glucose in postpartum cows. Variation in energy balance in our study was probably not sufficient for differences to occur in plasma glucose. Similar to MUN, plasma urea-N concentrations of cows fed DMP_AE or DMP_EE were lower in comparison with AMP_AE-fed cows, whereas feeding DMP_DE did not allow a significant reduction. This observation is in agreement with the calculation of the MP use efficiency. Indeed, the pattern of plasma urea concentrations is normally the reverse of estimated efficiencies of MP (Omphalius et al., 2020).

Feeding DMP diets did not decrease plasma His, Lys, and Met concentrations compared with the AMP diet (Table 9), which indicate that we were able to provide an equivalent level of these EAA within all treatments. Indeed, even though MP supply with DMP diets averaged only $83 \%$ of the supply from the AMP diet, the predicted digestible flows of His, Lys, and Met with DMP diets averaged, respectively, 93, 91, and $91 \%$ of the supply from the AMP diet. Predicted digestible flows of the other EAA with the DMP diets averaged between 80 and $89 \%$ of the supply from the AMP diet (Table 3). Diets did not affect the plasma concentration of the other EAA except for the branched-chain AA (BCAA). The DMP_AE-fed cows had lower plasma concentrations when compared with AMP_AE-fed

Table 9. Effect of MP and energy supplies on plasma AA concentrations $(\mu M)$ in dairy cows

\begin{tabular}{|c|c|c|c|c|c|c|}
\hline \multirow[b]{2}{*}{ AA } & \multicolumn{4}{|c|}{ Diet $^{1}$} & \multirow[b]{2}{*}{ SEM } & \multirow[b]{2}{*}{$P$-value } \\
\hline & $\mathrm{AMP} \_\mathrm{AE}$ & DMP_DE & DMP_AE & DMP_EE & & \\
\hline Ala & 268 & 251 & 251 & 260 & 12.6 & 0.33 \\
\hline Asp & 8.2 & 8.1 & 7.8 & 7.9 & 0.79 & 0.98 \\
\hline Cys & 103 & 105 & 106 & 100 & 3.4 & 0.35 \\
\hline Gln & 271 & 265 & 284 & 289 & 13.1 & 0.56 \\
\hline Glu & 67.2 & 65.6 & 72.6 & 69.7 & 3.80 & 0.20 \\
\hline Gly & $285^{\mathrm{b}}$ & $259^{\mathrm{b}}$ & $302^{\mathrm{ab}}$ & $351^{\mathrm{a}}$ & 14.8 & $<0.01$ \\
\hline His & 50.9 & 53.7 & 52.3 & 51.0 & 2.31 & 0.81 \\
\hline Ile & $114^{\mathrm{a}}$ & $88.9^{\mathrm{b}}$ & $83.4^{\mathrm{b}}$ & $100^{\mathrm{ab}}$ & 6.37 & $<0.01$ \\
\hline Leu & $134^{\mathrm{a}}$ & $112^{\mathrm{ab}}$ & $109^{\mathrm{b}}$ & $112^{\mathrm{ab}}$ & 8.2 & 0.03 \\
\hline Lys & 89.4 & 85.1 & 80.8 & 85.1 & 4.16 & 0.50 \\
\hline Met & 39.6 & 40.1 & 44.4 & 40.5 & 1.98 & 0.30 \\
\hline Phe & 44.0 & 41.6 & 44.1 & 41.2 & 2.06 & 0.52 \\
\hline Pro & $81.7^{\mathrm{a}}$ & $67.9^{\mathrm{b}}$ & $70.6^{\mathrm{b}}$ & $71.0^{\mathrm{b}}$ & 2.80 & $<0.01$ \\
\hline Ser & 84.4 & 75.6 & 80.1 & 80.8 & 4.19 & 0.43 \\
\hline Thr & 100 & 84.8 & 90.6 & 97.1 & 6.81 & 0.07 \\
\hline Trp & 60.8 & 55.3 & 53.1 & 56.6 & 2.34 & 0.17 \\
\hline Tyr & 47.3 & 38.3 & 40.3 & 42.6 & 2.47 & 0.06 \\
\hline Val & $230^{\mathrm{a}}$ & $211^{\mathrm{ab}}$ & $190^{\mathrm{b}}$ & $210^{\mathrm{ab}}$ & 13.0 & 0.04 \\
\hline
\end{tabular}

${ }^{\mathrm{a}, \mathrm{b}}$ Within a row, means without a common superscript letter differ $(P \leq 0.05)$.

${ }^{1}$ Diets formulated to meet: 100\% of MP and energy requirement = AMP_AE; $90 \%$ of MP requirement and $94 \%$ of energy requirement $=\mathrm{DMP} \_\mathrm{DE} ; 90 \%$ of MP requirement and 99\% of energy requirement $=\mathrm{DMP} \_\mathrm{AE} ; 90 \%$ of MP requirement and $104 \%$ of energy requirement $=$ DMP_EE 
Table 10. Effect of MP and energy supplies on milk fatty acid composition (g/100 g of total fatty acid) in dairy cows

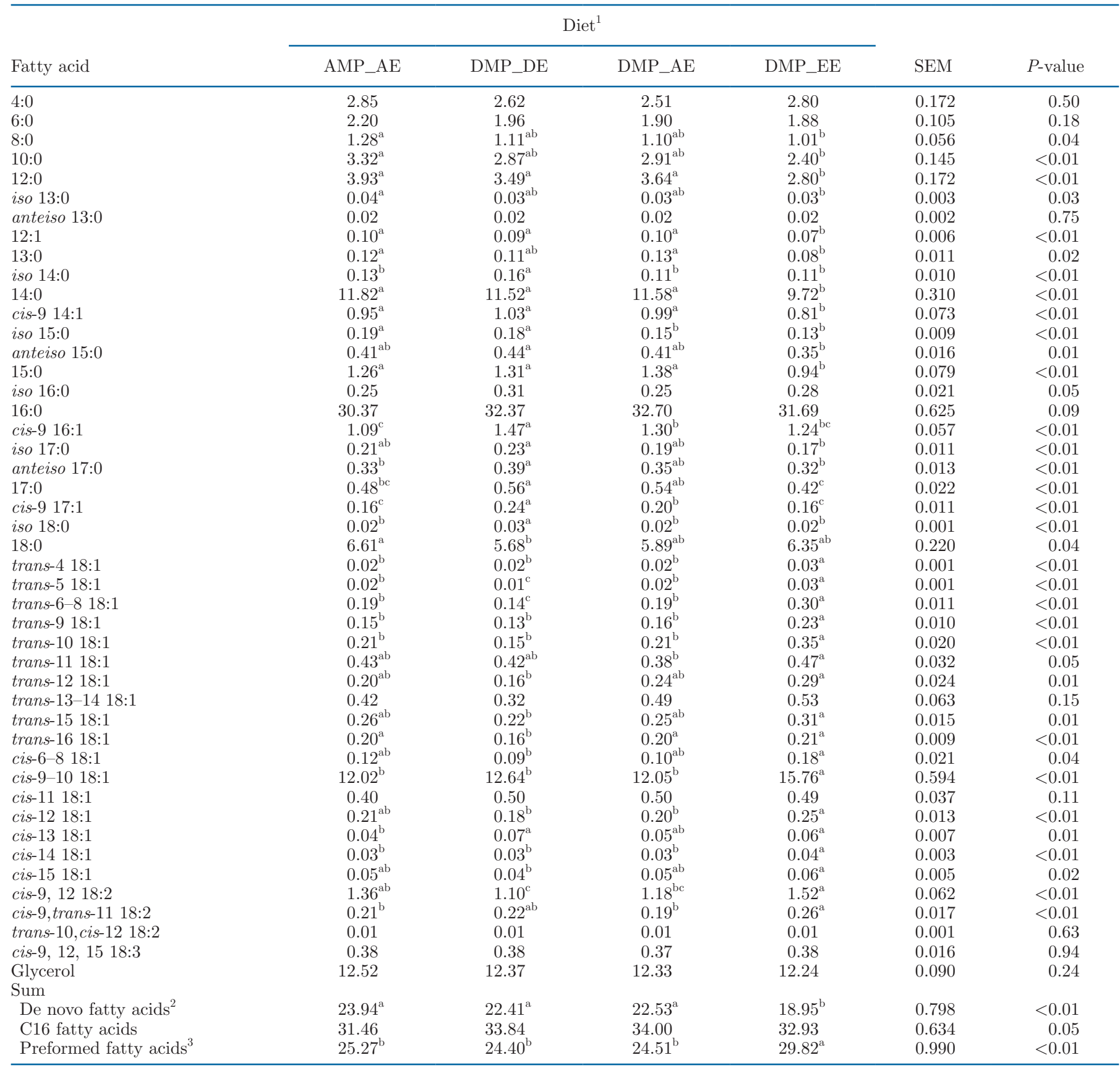

${ }^{\mathrm{a}-\mathrm{c}}$ Within a row, means without a common superscript letter differ $(P \leq 0.05)$.

${ }^{1}$ Diets formulated to meet: $100 \%$ of MP and energy requirement $=$ AMP_AE; $90 \%$ of MP requirement and $94 \%$ of energy requirement $=$ DMP DE; $90 \%$ of MP requirement and 99\% of energy requirement = DMP_AE; 90\% of MP requirement and 104\% of energy requirement = DMP_EE. ${ }^{2}$ Sum of straight even-chain fatty acids from C6 to C14.

${ }^{3}$ Sum of odd- and branched-chain fatty acids, and all fatty acids with a carbon chain length of 17 or more.

cows, although plasma BCAA concentrations were not different between cows receiving the DMP diets (Table 9). From this observation, 2 points can be discussed. First, the BCAA showed the largest numerical decrease in their plasma concentrations among the EAA despite a similar decrease in their supply with the DMP rations. This might be related to the fact that the BCAA are barely removed by the liver, and therefore, any change in their supply is more reflected in their peripheral concentrations than for the EAA removed sub- 
stantially by the liver such as Phe and Trp (Lapierre et al., 2012). Second, the DMP_AE diet had the highest NFC concentration, and plasma glucose concentration was numerically higher with cows receiving this treatment. Increased glucose supply, often related to higher plasma glucose concentration, has been reported to decrease plasma BCAA concentrations (Nichols at al., 2016), which might explain this observation. Among the NEAA, only plasma Gly and Pro concentrations were affected by the reduction of MP supply. Cows receiving DMP diets had lower plasma Pro concentration when compared with AMP_AE-fed cows. This might be related to the lower Arg digestible flow with the MP diets, Arg being an important precursor of Pro into milk protein mammary synthesis. On the opposite, plasma Gly concentration was increased when cows received DMP_EE diets in comparison with AMP_AE or DMP_DE; DMP_AE-fed cows had an intermediate value. Lee et al. (2012c) also observed an increased plasma concentration of Gly with low-MP diets. However, mechanisms involved with this observation are not clear (Lee et al., 2012c).

When compared with all other diets, milk concentration of most de novo fatty acids was reduced whereas the sum of preformed fatty acids was increased when cows were fed DMP_EE (Table 10). This effect is mainly explained by an increase in the concentration of cis-9-10 18:1 in milk of cows fed DMP_EE. Compared with other diets, DMP_EE had a greater concentration of most fatty acids, especially 16:0 and cis-9 18:1 (Table 2), the 2 main fatty acids contained in Ca salts of long-chain fatty acids used in the current study. Long-chain fatty acids derived from the diets inhibit the synthesis of malonyl-CoA and, thus, the de novo synthesis of fatty acids with 6 to 16 carbons by the mammary cells (Beaulieu and Palmquist, 1995; Emery, 1973). As opposed to other de novo fatty acids, milk 16:0 concentration was not significantly different among treatments, most probably due to the double origin (de novo synthesis and preformed) of this specific fatty acid. Several intermediates of the biohydrogenation pathway of unsaturated fatty acids (trans-4 18:1, trans-5 18:1, trans-6-8 18:1, trans-9 18:1, and trans-10 18:1) were in greater concentration in milk of cows fed DMP_EE in comparison with cows fed all other diets. Trans-18:1 fatty acids are derived from incomplete biohydrogenation of dietary UFA in the rumen (Jenkins and McGuire, 2006). The effect of DMP_EE on milk fat concentrations of biohydrogenation intermediates suggests that the Ca salts of long-chain fatty acids, added in the largest proportion in this diet (Table 2), may not be totally inert in the rumen. As demonstrated by Jenkins and Bridges (2007), protected fat sources, such as Ca salts, still release some fatty acids in the rumen. In addition, because of its potential inhibitory effect on rumen lipolysis and subsequent biohydrogenation (Gerson et al., 1983), the lack of RDP in DMP_EE diet might also have contributed to this observation (Leduc et al., 2017).

\section{CONCLUSIONS}

Our results showed that a reduction of MP supply below estimated MP requirements does not reduce milk, milk component, and ECM yields as long as His, Lys, Met, and energy requirements are met. This dietary strategy, however, improved $\mathrm{N}$ efficiency and the efficiency of utilization of MP and EAA, while decreasing $\mathrm{N}$ excretion by $24 \%$. Such changes would reduce N excretion and thereby decrease the environmental impact of milk production. This study shows that, when formulating diets for dairy cattle, emphasis should be placed on covering EAA rather than MP requirements, as long as RDP requirements are met.

\section{ACKNOWLEDGMENTS}

This research was funded by the Consortium de Recherche et Innovations en Bioprocédés Industriels au Québec (Québec, QC, Canada), Novalait (Québec, QC, Canada), and the Natural Sciences and Engineering Research Council of Canada (Ottawa, ON, Canada), with a contribution from the Centre de Recherche en Sciences Animales de Deschambault (Deschambault, QC, Canada). The first author received a scholarship from the Canadian Dairy Commission (Ottawa, ON, Canada) in collaboration with Novalait, and from the Fonds de Recherche du Québec-Nature et Technologies (Québec, QC, Canada). The authors are grateful to Yolaine Lebeuf and Nancy Bolduc from Université Laval (Québec, QC, Canada), and Geneviève Bégin, Camille Lambert-Beaudet, Danielle Bournival, Mario Léonard, and Jocelyne Renaud from Agriculture and Agri-Food Canada (Québec and Sherbrooke, QC, Canada) for professional and technical assistance. Recognition is also addressed to Annie Dumas, Jonathan Moreau, and Emmy Jacobs from the Centre de Recherche en Sciences Animales de Deschambault (Deschambault, QC, Canada) for their help at the barn. The authors have not stated any conflicts of interest.

\section{REFERENCES}

Allen, M. S. 2000. Effects of diet on short-term regulation of feed intake by lactating dairy cattle. J. Dairy Sci. 83:1598-1624. https:// doi.org/10.3168/jds.S0022-0302(00)75030-2.

AOAC (Association of Official Analytical Chemists). 1990. Method 973.18. Official Method of Analysis. 15th ed. AOAC. 
AOAC International. 2005. Method 920.39. Official Methods of Analysis. 18th ed. AOAC International.

Arriola Apelo, S. I., A. L. Bell, K. Estes, J. Ropelewski, M. J. de Veth, and M. D. Hanigan. 2014. Effects of reduced dietary protein and supplemental rumen-protected essential amino acids on the nitrogen efficiency of dairy cows. J. Dairy Sci. 97:5688-5699. https:// doi.org/10.3168/jds.2013-7833.

Beaulieu, A. D., and D. L. Palmquist. 1995. Differential effects of high fat diets on fatty acid composition in milk of Jersey and Holstein cows. J. Dairy Sci. 78:1336-1344. https://doi.org/10.3168/ jds.S0022-0302(95)76755-8.

Boivin, M., R. Gervais, and P. Y. Chouinard. 2013. Effect of grain and forage fractions of corn silage on milk production and composition in dairy cows. Animal 7:245-254. https://doi.org/10.1017/ S1751731112001486.

Boucher, S. E., R. S. Ordway, N. L. Whitehouse, F. P. Lundy, P. J. Kononoff, and C. G. Schwab. 2007. Effect of incremental urea supplementation of a conventional corn silage-based diet on ruminal ammonia concentration and synthesis of microbial protein. J. Dairy Sci. 90:5619-5633. https://doi.org/10.3168/jds.2007-0012.

Broderick, G. A. 2003. Effects of varying dietary protein and energy levels on the production of lactating dairy cows. J. Dairy Sci. 86:1370-1381. https://doi.org/10.3168/jds.S0022-0302(03)73721 $-7$.

Broderick, G. A. 2018. Optimizing ruminant conversion of feed protein to human food protein. Animal 12:1722-1734. https://doi.org/10 .1017/S1751731117002592

Brun-Lafleur, L., L. Delaby, F. Husson, and P. Faverdin. 2010. Predicting energy $\times$ protein interaction on milk yield and milk composition in dairy cows. J. Dairy Sci. 93:4128-4143. https://doi .org/10.3168/jds.2009-2669.

Calder, A. G., K. E. Garden, S. E. Anderson, and G. E. Lobley. 1999. Quantitation of blood and plasma amino acids using isotope dilution electron impact gas chromatography/mass spectrometry with $\mathrm{U}_{-}{ }^{13} \mathrm{C}$ amino acids as internal standards. Rapid Commun. Mass Spectrom. 13:2080-2083. https://doi.org/10.1002/(SICI)1097 -0231(19991115)13:21<2080::AID-RCM755>3.0.CO;2-O.

CCAC (Canadian Council on Animal Care). 2009. Guide to the Care and Use of Experimental Animals. 2nd ed. Vol. 1. Canadian Council on Animal Care.

Chen, X. B., and M. J. Gomes. 1992. Estimation of microbial protein supply to sheep and cattle based on urinary excretion of purine derivatives: An overview of technical details. Int. Feed Res. Unit, Occasional Publ. Rowett Research Institute.

Coblentz, W. K., K. P. Coffey, and E. A. Chow. 2016. Storage characteristics, nutritive value, and fermentation characteristics of alfalfa packaged in large-round bales and wrapped in stretch film after extended time delays. J. Dairy Sci. 99:3497-3511. https://doi.org/ $10.3168 /$ jds. 2015-10380.

Doepel, L., and H. Lapierre. 2010. Changes in production and mammary metabolism of dairy cows in response to essential and nonessential amino acid infusions. J. Dairy Sci. 93:3264-3274. https:// doi.org/10.3168/jds.2009-3033.

Doepel, L., D. Pacheco, J. J. Kennelly, M. D. Hanigan, I. F. Lopez, and H. Lapierre. 2004. Milk protein synthesis as a function of amino acid supply. J. Dairy Sci. 87:1279-1297. https://doi.org/10 .3168/jds.S0022-0302(04)73278-6.

Edmonson, A. J., I. J. Lean, L. D. Weaver, T. Farver, and G. Webster. 1989. A body condition scoring chart for Holstein dairy cows. J. Dairy Sci. 72:68-78. https://doi.org/10.3168/jds.S0022 -0302(89)79081-0.

Emery, R. S. 1973. Biosynthesis of milk fat. J. Dairy Sci. 56:11871195. https://doi.org/10.3168/jds.S0022-0302(73)85334-2.

George, S. K., M. T. Dipu, U. R. Mehra, P. Singh, A. K. Verma, and J. S. Ramgaokar. 2006. Improved HPLC method for the simultaneous determination of allantoin, uric acid and creatinine in cattle urine. J. Chromatogr. B Analyt. Technol. Biomed. Life Sci. 832:134-137. https://doi.org/10.1016/j.jchromb.2005.10.051.

Gerson, T., A. John, and B. R. Sinclair. 1983. The effect of dietary $\mathrm{N}$ on in vitro lipolysis and fatty acid hydrogenation in rumen di- gesta from sheep fed diets high in starch. J. Agric. Sci. (Camb.) 101:97-101. https://doi.org/10.1017/S0021859600036406.

Giallongo, F., M. T. Harper, J. Oh, J. C. Lopes, H. Lapierre, R. A. Patton, C. Parys, I. Shinzato, and A. N. Hristov. 2016. Effects of rumen-protected methionine, lysine, and histidine on lactation performance of dairy cows. J. Dairy Sci. 99:4437-4452. https://doi .org/10.3168/jds.2015-10822.

Giallongo, F., A. N. Hristov, J. Oh, T. Frederick, H. Weeks, J. Werner, H. Lapierre, R. A. Patton, A. Gehman, and C. Parys. 2015. Effects of slow-release urea and rumen-protected methionine and histidine on performance of dairy cows. J. Dairy Sci. 98:3292-3308. https:/ /doi.org/10.3168/jds.2014-8791.

Goering, H. K., and P. J. Van Soest. 1970. Forage fiber analysis. Apparatus, reagents, procedures and some applications. Agric. Handbook 379:20.

Gressley, T. F., and L. E. Armentano. 2007. Effects of low rumendegradable protein or abomasal fructan infusion on diet digestibility and urinary nitrogen excretion in lactating dairy cows. J. Dairy Sci. 90:1340-1353. https://doi.org/10.3168/jds.S0022 -0302(07)71621-1.

Grev, A. M., M. S. Wells, D. A. Samac, K. L. Martinson, and C. C. Sheaffer. 2017. Forage accumulation and nutritive value of reduced lignin and reference alfalfa cultivars. Agron. J. 109:2749-2761. https://doi.org/10.2134/agronj2017.04.0237.

Hatfield, R. D., J. Ralph, and J. H. Grabber. 1999. Cell wall structural foundations: Molecular basis for improving forage digestibilities. Crop Sci. 39:27-37. https://doi.org/10.2135/cropsci1999 $.0011183 X 003900010005 x$.

Hoffman, P. C., D. K. Combs, and M. D. Casler. 1998. Performance of lactating dairy cows fed alfalfa silage or perennial ryegrass silage. J. Dairy Sci. 81:162-168. https://doi.org/10.3168/jds.S0022 -0302(98)75563-8

Holt, M. S., K. Neal, J.-S. Eun, A. J. Young, J. O. Hall, and K. E. Nestor Jr.. 2013. Corn silage hybrid type and quality of alfalfa hay affect dietary nitrogen utilization by early lactating dairy cows. J. Dairy Sci. 96:6564-6576. https://doi.org/10.3168/jds.2013-6689.

Hristov, A. N., M. Hanigan, A. Cole, R. Todd, T. A. McAllister, P. M. Ndegwa, and A. Rotz. 2011. Ammonia emissions from dairy farms and beef feedlots. Can. J. Anim. Sci. 91:1-35. https://doi.org/10 4141/CJAS10034.

Hristov, A. N., K. Heyler, E. Schurman, K. Griswold, P. Topper, M. Hile, V. Ishler, E. Fabian-Wheeler, and S. Dinh. 2015. CASE STUDY: Reducing dietary protein decreased the ammonia emitting potential of manure from commercial dairy farms. Prof. Anim. Sci. 31:68-79. https://doi.org/10.15232/pas.2014-01360.

Huhtanen, P., and M. Hetta. 2012. Comparison of feed intake and milk production responses in continuous and change-over design dairy cow experiments. Livest. Sci. 143:184-194. https://doi.org/ 10.1016/j.livsci.2011.09.012.

Huhtanen, P., and A. N. Hristov. 2009. A meta-analysis of the effects of dietary protein concentration and degradability on milk protein yield and milk N efficiency in dairy cows. J. Dairy Sci. 92:32223232. https://doi.org/10.3168/jds.2008-1352.

Huhtanen, P., A. Vanhatalo, and T. Varvikko. 2002. Effects of abomasal infusions of histidine, glucose, and leucine on milk production and plasma metabolites of dairy cows fed grass silage diets. J. Dairy Sci. 85:204-216. https://doi.org/10.3168/jds.S0022 -0302(02)74069-1.

Huntington, G. B. 1984. Net absorption of glucose and nitrogenous compounds by lactating Holstein cows. J. Dairy Sci. 67:1919-1927. https://doi.org/10.3168/jds.S0022-0302(84)81525-8.

INRA (Institut National de Recherche Agronomique). 2018. Feeding system for ruminants. Wageningen Academic Publishers. https:// doi.org/10.3920/978-90-8686-292-4.

Isaac, R. A., and W. C. Johnson. 1976. Determination of total nitrogen in plant tissue, using a block digestor. J. Assoc. Off. Anal. Chem. 59:98-100. https://doi.org/10.1093/jaoac/59.1.98.

Jenkins, T. C. 2010. Common analytical errors yielding inaccurate results during analysis of fatty acids in feed and digesta samples. J. Dairy Sci. 93:1170-1174. https://doi.org/10.3168/jds.2009-2509. 
Jenkins, T. C., and W. C. Bridges Jr.. 2007. Protection of fatty acids against ruminal biohydrogenation in cattle. Eur. J. Lipid Sci. Technol. 109:778-789. https://doi.org/10.1002/ejlt.200700022.

Jenkins, T. C., and M. A. McGuire. 2006. Major advances in nutrition: impact on milk composition. J. Dairy Sci. 89:1302-1310. https:// doi.org/10.3168/jds.S0022-0302(06)72198-1.

Julier, B., and C. Huyghe. 1997. Effect of growth and cultivar on alfalfa digestibility in a multi-site trial. Agronomie 17:481-489. https://doi.org/10.1051/agro:19970905.

Jung, H. G., and M. S. Allen. 1995. Characteristics of plant cell walls affecting intake and digestibility of forages by ruminants. J. Anim. Sci. 73:2774-2790. https://doi.org/10.2527/1995.7392774x.

Külling, D. R., H. Menzi, T. F. Kröber, A. Neftel, F. Sutter, P. Lischer, and M. Kreuzer. 2001. Emissions of ammonia, nitrous oxide and methane from different types of dairy manure during storage as affected by dietary protein content. J. Agric. Sci. (Camb.) 137:235-250. https://doi.org/10.1017/S0021859601001186.

Lachat Instruments. 2019. Methods List for Automated Ion Analyzers (Flow Injection Analyses-Ion Chromatography). Hach. Accessed Sep. 23, 2021. https://www.hach.com/asset-get.download.jsa?id= 33850703651.

Lapierre, H., G. E. Lobley, L. Doepel, G. Raggio, H. Rulquin, and S. Lemosquet. 2012. Triennial Lactation Symposium: Mammary metabolism of amino acids in dairy cows. J. Anim. Sci. 90:1708-1721. https://doi.org/10.2527/jas.2011-4645.

Lapierre, H., G. E. Lobley, and D. R. Ouellet. 2021. Histidine optimal supply in dairy cows through determination of a threshold efficiency. J. Dairy Sci. 104:1759-1776. https://doi.org/10.3168/jds .2020-19205.

Lapierre, H., R. Martineau, M. D. Hanigan, H. J. van Lingen, E. Kebreab, J. W. Spek, and D. R. Ouellet. 2020. Review: Impact of protein and energy supply on the fate of amino acids from absorption to milk protein in dairy cows. Animal 14:s87-s102. https://doi .org/10.1017/S1751731119003173.

Lauzon, J., G. F. Tremblay, G. Bélanger, P. Seguin, J. Lajeunesse, and R. Gervais. 2019. Alfalfa and timothy nutritive value in contrasting agroclimatic regions. Agron. J. 111:1371-1380. https:// doi.org/10.2134/agronj2018.10.0634.

Leduc, M., R. Gervais, G. F. Tremblay, J. Chiquette, and P. Y. Chouinard. 2017. Milk fatty acid profile in cows fed red clover- or alfalfasilage based diets differing in rumen-degradable protein supply. Anim. Feed Sci. Technol. 223:59-72. https://doi.org/10.1016/j .anifeedsci.2016.11.001.

Lee, C., A. N. Hristov, T. W. Cassidy, K. S. Heyler, H. Lapierre, G. A. Varga, M. J. De Veth, R. A. Patton, and C. Parys. 2012c. Rumenprotected lysine, methionine, and histidine increase milk protein yield in dairy cows fed a metabolizable protein-deficient diet. J. Dairy Sci. 95:6042-6056. https://doi.org/10.3168/jds.2012-5581.

Lee, C., A. N. Hristov, C. J. Dell, G. W. Feyereisen, J. Kaye, and D. Beegle. 2012a. Effect of dietary protein concentration on ammonia and greenhouse gas emitting potential of dairy manure. J. Dairy Sci. 95:1930-1941. https://doi.org/10.3168/jds.2010-4141.

Lee, C., A. N. Hristov, K. S. Heyler, T. W. Cassidy, H. Lapierre, G. A. Varga, and C. Parys. 2012b. Effects of metabolizable protein supply and amino acid supplementation on nitrogen utilization, milk production, and ammonia emissions from manure in dairy cows. J. Dairy Sci. 95:5253-5268. https://doi.org/10.3168/jds.2012-5366.

Lee, C., A. N. Hristov, K. S. Heyler, T. W. Cassidy, M. Long, B. A. Corl, and S. K. R. Karnati. 2011. Effects of dietary protein concentration and coconut oil supplementation on nitrogen utilization and production in dairy cows. J. Dairy Sci. 94:5544-5557. https:/ /doi.org/10.3168/jds.2010-3889.

Madsen, T. G., M. O. Nielsen, J. B. Andersen, and K. L. Ingvartsen. 2008. Continuous lactation in dairy cows: Effect on milk production and mammary nutrient supply and extraction. J. Dairy Sci. 91:1791-1801. https://doi.org/10.3168/jds.2007-0905.

Martineau, R., D. R. Ouellet, E. Kebreab, and H. Lapierre. 2016. Casein infusion rate influences feed intake differently depending on metabolizable protein balance in dairy cows: A multilevel metaanalysis. J. Dairy Sci. 99:2748-2761. https://doi.org/10.3168/jds .2015-10427.
Mertens, D. R. 2002. Gravimetric determination of amylase-treated neutral detergent fiber in feeds with refluxing in beakers or crucibles: Collaborative study. J. AOAC Int. 85:1217-1240. https:// doi.org/10.1093/jaoac/85.6.1217.

Nichols, K., A. Bannink, S. Pacheco, H. J. Van Valenberg, J. Dijkstra, and H. Van Laar. 2018. Feed and nitrogen efficiency are affected differently but milk lactose production is stimulated equally when isoenergetic protein and fat is supplemented in lactating dairy cow diets. J. Dairy Sci. 101:7857-7870. https://doi.org/10.3168/jds .2017-14276.

Nichols, K., J. Dijkstra, H. Van Laar, S. Pacheco, H. J. Van Valenberg, and A. Bannink. 2019. Energy and nitrogen partitioning in dairy cows at low or high metabolizable protein levels is affected differently by postrumen glucogenic and lipogenic substrates. J. Dairy Sci. 102:395-412. https://doi.org/10.3168/jds.2018-15249.

Nichols, K., J. J. M. Kim, M. Carson, J. A. Metcalf, J. P. Cant, and J. Doelman. 2016. Glucose supplementation stimulates peripheral branched-chain amino acid catabolism in lactating dairy cows during essential amino acid infusions. J. Dairy Sci. 99:1145-1160. https://doi.org/10.3168/jds.2015-9912.

NorFor. 2011. The Nordic feed evaluation system. EAAP Publication No. 130. Wageningen Academic Publishers.

NRC (National Research Council). 2001. Nutrient Requirements of Dairy Cattle. Seventh revised edition ed. National Academy Press.

Oba, M., and M. S. Allen. 1999. Evaluation of the importance of the digestibility of neutral detergent fiber from forage: Effects on dry matter intake and milk yield of dairy cows. J. Dairy Sci. 82:589596. https://doi.org/10.3168/jds.S0022-0302(99)75271-9.

Omphalius, C., H. Lapierre, L. Bahloul, and S. Lemosquet. 2019b. Responses to methionine, lysine plus histidine at two levels of energy in dairy cows. Pages 5876-5887 in EAAP Scientific Series. Wageningen Academic Publishers. https://doi.org/10.3920/978-90 -8686-891-9_44.

Omphalius, C., H. Lapierre, J. Guinard-Flament, P. Lamberton, L. Bahloul, and S. Lemosquet. 2019a. Amino acid efficiencies of utilization vary by different mechanisms in response to energy and protein supplies in dairy cows: Study at mammary-gland and whole-body levels. J. Dairy Sci. 102:9883-9901. https://doi.org/ 10.3168/jds.2019-16433.

Omphalius, C., S. Lemosquet, D. R. Ouellet, L. Bahloul, and H. Lapierre. 2020. Postruminal infusions of amino acids or glucose affect metabolisms of splanchnic, mammary, and other peripheral tissues and drive amino acid use in dairy cows. J. Dairy Sci. 103:22332254. https://doi.org/10.3168/jds.2019-17249.

Owens, F. N., S. Qi, and D. A. Sapienza. 2014. Invited Review: Applied protein nutrition of ruminants - Current status and future directions. Prof. Anim. Sci. 30:150-179. https://doi.org/10.15232/ S1080-7446(15)30102-9.

Raggio, G., S. Lemosquet, G. E. Lobley, H. Rulquin, and H. Lapierre. 2006. Effect of casein and propionate supply on mammary protein metabolism in lactating dairy cows. J. Dairy Sci. 89:4340-4351. https://doi.org/10.3168/jds.S0022-0302(06)72481-X.

Robinson, P. H. 2010. Impacts of manipulating ration metabolizable lysine and methionine levels on the performance of lactating dairy cows: A systematic review of the literature. Livest. Sci. 127:115126. https://doi.org/10.1016/j.livsci.2009.10.003.

Sauvant, D., P. Nozière, and R. Baumont. 2014. Development of a mechanistic model of intake, chewing and digestion in cattle in connection with updated feed units. Anim. Prod. Sci. 54:21122120. https://doi.org/10.1071/AN14528.

Schwab, C. G., and G. A. Broderick. 2017. A 100-Year Review: Protein and amino acid nutrition in dairy cows. J. Dairy Sci. 100:1009410112. https://doi.org/10.3168/jds.2017-13320.

Sok, M., D. R. Ouellet, J. L. Firkins, D. Pellerin, and H. Lapierre. 2017. Amino acid composition of rumen bacteria and protozoa in cattle. J. Dairy Sci. 100:5241-5249. https://doi.org/10.3168/ jds.2016-12447.

Statistics Canada. 2021. Table: 32-10-0043-01 - Forage seed usage by type of seed. Accessed Feb. 7, 2021. https://www150.statcan.gc .ca/t1/tbl1/fr/tv.action?pid=3210004301. 
Urdl, M., L. Gruber, W. Obritzhauser, and A. Schauer. 2015. Metabolic parameters and their relationship to energy balance in multiparous Simmental, Brown Swiss and Holstein cows in the periparturient period as influenced by energy supply pre-and post-calving. J. Anim. Physiol. Anim. Nutr. (Berl.) 99:174-189. https://doi.org/ 10.1111/.jpn.12178.

Vérité, R., and L. Delaby. 2000. Relation between nutrition, performances and nitrogen excretion in dairy cows. Ann. Zootech. 49:217-230. https://doi.org/10.1051/animres:2000101.

Vough, L. R., and G. C. Marten. 1971. Influence of soil moisture and ambient temperature on yield and quality of alfalfa forage. Agron. J. 63:40-42. https://doi.org/10.2134/agronj1971 $.00021962006300010014 \mathrm{x}$.

Whitehouse, N., C. Schwab, D. Luchini, and B. Sloan. 2010a. A critique of dose-response plots that relate changes in content and yield of milk protein to predicted concentrations of lysine in metabolizable protein by the NRC (2001), CPM-Dairy (v. 3.0.10), and AMTS. Cattle (v. 2.1.1) models. J. Dairy Sci. 93(E-Suppl. 1):447. (Abstr.)
Whitehouse, N., C. Schwab, D. Luchini, and B. Sloan. 2010b. A critique of dose-response plots that relate changes in content and yield of milk protein to predicted concentrations of methionine in metabolizable protein by the NRC (2001), CPM-Dairy (v. 3.0.10), and AMTS. Cattle (v. 2.1.1) models. J. Dairy Sci. 93(E-Suppl. $1): 449$.

\section{ORCIDS}

J.-P. Laroche ำ https://orcid.org/0000-0001-7310-6584

R. Gervais ๑ https://orcid.org/0000-0002-6929-2027

H. Lapierre ๑ https://orcid.org/0000-0002-1162-7226

D. R. Ouellet (ํ) https://orcid.org/0000-0002-9835-0767

G. F. Tremblay $\odot$ https://orcid.org/0000-0001-7652-8985

C. Halde ำ https://orcid.org/0000-0002-4974-1411

M.-S. Boucher @ https://orcid.org/0000-0002-0333-4589

É. Charbonneau ๑ https://orcid.org/0000-0002-0675-3076 